\title{
PAKET MATERI PEMBELAJARAN INKUIRI DALAM PENDIDIKAN LINGKUNGAN HIDUP UNTUK MENINGKATKAN PERILAKU BERWAWASAN LINGKUNGAN SISWA SD DI JAKARTA
}

\author{
BINTANG RUMONDANG SIMBOLON \\ Dosen Universitas Kristen (UKI) Jakarta
}

\begin{abstract}
The objective of the research is to develop an environmental inquiry education material package to increase the environmental behavior of the Elementary students. The research was designed by using research and development ( $R \& D)$ method. The stages of the research are: (1) to initate the material package, (2) to validate the materials by using randomized control-group posttest method for every try-out, and (3) to recommend the materials. In this study, instruments collected important informations such as: (1) need assessment from the teachers, parents and students from Elementary school, (2) environmental behavior possessed by the students. Research findings show that there is a bigger environmental behavior score obtained by inquiry instructional materials treated group compared to conventional method control group. Based on findings, it could be concluded that the inquiry material package is effective in enhancing the environmental behavior of the students. Therefore, this material package could be recommended for wider application.
\end{abstract}

\section{PENDAHULUAN}

Dewasa ini banyak terjadi kerusakan lingkungan seiring dengan perkembangan dan kemajuan teknologi serta tingginya angka pertumbuhan penduduk. Kondisi ini menyebabkan kemerosotan kualitas kehidupan dan lingkungan hidup. Pemanfaatan produk teknologi belum sepenuhnya mampu menjamin peningkatan kualitas kehidupan dan lingkungan.

Perkembangan teknologi dapat dianggap seperti dua sisi mata uang. Di satu sisi dia dapat mempermudah kehidupan umat manusia, namun di sisi lain dapat menurunkan kualitas lingkungan. Hal ini terjadi karena seringkali dalam pembangunan digunakan teknologi yang dapat mencemari dan menghasilkan limbah. Pada jangka panjang, penurunan kualitas lingkungan ini akan berkorelasi secara signifikan dengan penurunan kualitas kehidupan.

Pembangunan berkelanjutan (sustainable development) menurut komisi dunia untuk lingkungan dan pembangunan (WCED - World Commission on Environment and Development) adalah pembangunan yang ditujukan untuk memenuhi kebutuhan generasi sekarang tanpa mengorbankan kemampuan generasi yang akan datang untuk memenuhi kebutuhan mereka sendiri (Hadi, 2001: 2).

Di sisi lain dikenal suatu istilah yang berlawanan dengan pembangunan berkelanjutan yaitu Mentalitas frontier. Pandangan ini menempatkan manusia sebagai pusat alam semesta dan berhak mengeksploitasi alam untuk kepentingannya sendiri (Chiras, 1988: 455). Akibat dari asumsi ini manusia cenderung untuk mengeksploitasi sumber daya alam bagi kepentingan diri sendiri dan menganggap sumber daya alam bersifat tidak terbatas. Hal ini berkembang menjadi perilaku yang sangat individual dalam menghadapi masalah lingkungan, antara lain sikap apatis, berorientasi pada kepentingan diri sendiri, serta merasa tidak perlu ikut ambil bagian dalam masalah lingkungan.

Dampak yang lebih luas, timbul masyarakat yang memiliki sinergi rendah dalam menyikapi dan menghadapi berbagai masalah dan tantangan lingkungan hidup. Oleh karena itu diharapkan kita mempunyai etika yang harus merupakan etika masyarakat modern dewasa ini, sebagaimana yang dikemukakan oleh Chiras (1988: 445) yaitu Konsep Etika Lingkungan yang Berkelanjutan (Sustainable Ethics). Pandangan ini mempunyai pengertian bahwa tidak selalu ada yang berlebih, dalam arti bumi memiliki daya dukung yang terbatas.

New Environmental Paradigm (NEP) merupakan suatu sikap atau pandangan yang pada dasarnya menempatkan manusia sebagai bagian dari ekosistem, dan manusia begitu erat hubungannya dengan kehidupan seluruh kosmos. Jadi NEP melihat akal dan kebebasan manusia tidak hanya sebagai alat kebangkitan dan kebebasan manusia terhadap lingkungan alam, tetapi juga sebagai kebebasan dalam pengertian untuk mengelola sekaligus menjaganya.

Dalam paradigma baru ini, diharapkan manusia hendaknya berpikir dialektis, dalam arti bahwa kerusakan alam senantiasa berhubungan dengan ulah manusia. Kekayaan alam dan kelestarian daya dukungnya selalu berhubungan dengan tanggung jawab dan kesadaran ekologis manusia. Manusia merupakan bagian dari lingkungan hidupnya dan bukan terpisah dari padanya.

Salah satu upaya untuk menimbulkan kesadaran warga masyarakat dalam pengelolaan lingkungan juga dapat ditempuh melalui Pendidikan Lingkungan

\begin{tabular}{|l|l|l|l|}
\hline Volume XI & Nomor 02 & Maret 2010 & ISSN 1411-1829 \\
\hline
\end{tabular}


Hidup kepada siswa sejak pendidikan dasar. Hal ini sejalan dengan pendapat Suriasumantri (2000: 261 268) bahwa pendidikan dapat mengubah orientasi nilai budaya seseorang. Dalam hal ini, Pendidikan Lingkungan Hidup diharapkan mampu memainkan peranannya untuk membentuk manusia yang peduli terhadap lingkungannya sehingga dapat meminimalkan resiko-resiko kerusakan lingkungan. Hal ini diasumsikan bahwa dengan semakin bertambahnya pengetahuan seseorang, maka sikapnya menjadi semakin positif yang akan mengarahkannya untuk berperilaku yang berwawasan lingkungan.

Setelah hampir dua dasawarsa Pendidikan Lingkungan Hidup diperkenalkan di sekolah, hasil yang dicapai belum menggembirakan. Realita seharihari dapat kita lihat bahwa hampir semua siswa kurang menampilkan perilaku yang berwawasan lingkungan.

Dari hasil observasi pendahuluan pada salah satu SDN di daerah Rawamangun, peneliti memperoleh beberapa temuan. Pertama, ditemui perilaku siswa yang membuang sampah sembarangan, mencoretcoret bangku atau tembok kelas, membiarkan keran air mengalir di kamar mandi. Kedua, proses pembelajaran Pendidikan Lingkungan Hidup yang dilakukan oleh guru hanya terbatas pada transfer informasi, sehingga kurang memberi kesempatan pada siswa untuk berinteraksi langsung dengan obyek-obyek konkrit. Ketiga, penekanan hanya pada penyampaian materi dari buku paket yang ada sehingga keadaan ini mendorong siswa untuk menghafal saja. Keempat, metode mengajar yang selama ini berpusat pada guru yang menyebabkan para siswa menjadi pasif dan kurang dilatih untuk berpikir atau bertindak.

Pendidikan Lingkungan Hidup siswa SD di beberapa daerah belumlah sebagai program monolitik, tetapi masih terintegrasi pada beberapa pelajaran seperti Bahasa Indonesia, Ilmu Pengetahuan Sosial serta Ilmu Pengetahuan Alam. Di wilayah DKI Jakarta, Pendidikan Lingkungan Hidup sudah disampaikan dalam bentuk mata pelajaran tersendiri yaitu Pendidikan Lingkungan Kehidupan Jakarta (PLKJ) yang disusun berdasarkan Kurikulum Muatan Lokal Pendidikan Dasar DKI Jakarta tahun 2000 (Balitbang Depdiknas, 2000: 35). Materi PLKJ diberikan oleh guru-guru melalui metode pembelajaran konvensional atau dikenal dengan ekspositori. Yang menjadi pertanyaan sekarang adalah "Bagaimanakah paket materi pembelajaran Pendidikan Lingkungan yang dapat meningkatkan perilaku yang berwawasan lingkungan bagi siswa SD?”

Metode pembelajaran di kelas biasanya dilakukan secara konvensional, di mana guru membuat semua keputusan sedangkan siswa lebih bersifat pasif dan menerima apa yang disampaikan guru. Akibatnya siswa kurang memiliki rasa ingin tahu yang besar yang dapat menariknya untuk belajar lebih mendalam lagi tentang konsep yang sedang dipelajarinya. Metode pembelajaran inkuiri dianggap sesuai dan menjiwai langkah-langkah untuk mengaktifkan siswa sehingga siswa dapat menemukan konsep atau prinsip yang dilandasi oleh rasa keingintahuannya. Hal ini sejalan dengan pendapat yang menyatakan bahwa siswa akan lebih mudah mengingat apa yang dipelajarinya bila melihat obyeknya secara langsung, jika dibandingkan dengan siswa yang mendapatkan informasi secara verbal saja dalam pembelajaran konvensional (Henich, 1989: 13). Diharapkan dengan pengembangan metode pembelajaran inkuiri ini, siswa mampu memahami Pendidikan Lingkungan dengan baik dan benar sehingga siswa dapat bersikap semakin positif yang akan mengarahkannya untuk berperilaku yang berwawasan lingkungan.

Berdasarkan uraian di atas dilakukan penelitian dengan permasalahan yang dapat dirumuskan sebagai berikut :

1. Bagaimanakah pengembangan paket materi inkuiri Pendidikan Lingkungan Hidup di SD?

2. Materi-materi pokok Pendidikan Lingkungan Hidup apa saja bagi siswa SD yang diperlukan untuk dimasukkan ke dalam pengembangan materi tersebut?

3. Apakah paket materi yang dikembangkan tersebut efektif dalam meningkatkan perilaku berwawasan lingkungan bagi siswa SD?

\section{KAJIAN TEORETIK}

\section{Perilaku Berwawasan Lingkungan}

Perilaku adalah tindakan nyata atau gerakan seseorang dalam melakukan suatu kegiatan, juga termasuk di dalamnya perkataan, yang terjadi karena adanya rangsangan dari lingkungan maupun tidak. Dengan kata lain, perilaku individu atau kelompok bukan sekedar respon terhadap stimulus, tetapi juga produk dari berbagai tujuan dan kebutuhan yang mempengaruhi individu yang bersangkutan. Istilah lain yang sering digunakan sebagai pengganti kata perilaku adalah aktivitas, aksi, penampilan, reaksi atau respon (Martin\& Pear, 1992: 33).

Perilaku adalah tindakan yang dilakukan setelah hasil proses berpikir tentang suatu masukan yang diterima akal untuk dipraktekkan. Manusia dengan lingkungannya merupakan kesatuan yang tak dapat dipisahkan dan saling berinteraksi. Interaksi manusia dengan lingkungannya merupakan hubungan saling

\begin{tabular}{|l|c|c|c|}
\hline Volume XI & Nomor 02 & Maret 2010 & ISSN 1411-1829 \\
\hline
\end{tabular}


ketergantungan satu sama lainnya, artinya perilaku manusia mempengaruhi lingkungannya, sebaliknya lingkungan akan mempengaruhi perilaku dan pengalaman manusia itu sendiri (Gifford, 1987: 22). Melalui proses interaksi dengan lingkungan hidupnya, selain manusia akan mempengaruhi dan dipengaruhi oleh lingkungannya, ia juga membentuk dan terbentuk oleh lingkungan hidupnya (Soemarwoto, 1989: 51).

Rotter (http://psych.fullerton.e.u/jmeearns/rotter:htm 2001) menjelaskan bagaimana perilaku dapat dipelajari dan dimunculkan oleh seseorang dengan melihat interaksi seseorang dengan lingkungannya. Perilaku disebutkan sebagai respon secara otomatis terhadap obyek lingkungan. Perilaku yang dimunculkan oleh seseorang diarahkan oleh kebutuhan yang dimiliki, dan merupakan upaya untuk memperoleh penguatan (reinforcement), yang didapat di lingkungan keluarga, sekolah, tempat bekerja dan lingkungan lainnya.

Skinner sebagai seorang psychologist yang sangat terkenal pada abad XX mengatakan bahwa individu cenderung mengulangi perilaku atau perbuatannya karena adanya penghargaan (reward) dan tidak akan mengulangi perbuatannya karena yang bersangkutan mendapat hukuman (punishment). Teori ini lebih dikenal dengan istilah Operant Conditioning Theory, yaitu mengulangi perilakunya karena ada keuntungan (positive outcome) dan akan menjauhinya karena merugikan (negative outcome) (Berndt, 1997: 24).

Menurut Sarwono (1995: 37), perilaku adalah perbuatan-perbuatan manusia, baik yang terbuka (kasat indera) maupun yang tertutup (tidak kasat mata). Ia mengatakan bahwa perbuatan yang terbuka dinamakan overt behavior, yakni semua perilaku yang bisa ditangkap langsung dengan indera seperti: melempar, memukul, dan lain-lainnya, sedangkan perilaku yang tidak kasat mata (covert behavior) adalah yang harus diselidiki dengan metode atau instrumen khusus, karena tidak langsung dapat ditangkap indera misalnya motivasi, sikap, berpikir, beremosi, dan minat.

Sejalan dengan Sarwono, maka Krech (1988: 368 - 371), membagi perilaku menjadi perilaku yang teramati dan perilaku yang tersamar. Perilaku yang teramati adalah perilaku dalam bentuk aktif yang dapat diobservasi secara langsung dan dapat diserap oleh panca indera. Sedangkan perilaku yang tersamar adalah perilaku yang tidak nyata dalam bentuk pasif, dan tidak dapat langsung terlihat seperti persepsi, motivasi, dan sikap.

Perilaku dapat juga diartikan sebagai suatu cara atau perbuatan yang dilakukan manusia. Perilaku menurut Robin (2000: 25) dimaknai sebagai hasil perbuatan seseorang yang ditunjukkan secara terus menerus dan cenderung berkesinambungan akibat adanya situasi dan kondisi yang dihadapinya.

Pembentukan atau pengembangan perilaku melalui pendidikan baik secara formal maupun non formal adalah salah satu upaya yang dilakukan kepada anak untuk mampu memahami keadaan lingkungannya. Melalui kegiatan ini diharapkan terbentuk pribadi-pribadi yang peduli terhadap lingkungan dalam bentuk menjaga dan melestarikannya. Jika tidak, dari hari ke hari lingkungan akan terus menjadi rusak dan terjadi ketidakseimbangan alam yang pada akhirnya dapat menimbulkan malapetaka terhadap diri manusia sendiri.

Oleh karena itu, pada bidang-bidang ilmu tertentu seperti Pendidikan Lingkungan Hidup, pendidikan tidak hanya terfokus pada peningkatan pengetahuan (cognitive domain), tetapi juga perlu diarahkan pada pembentukan dan pengembangan perilaku yang seharusnya dimiliki seseorang dalam kaitannya dengan lingkungannya. Dengan demikian, hasil yang diharapkan dari proses belajar mengajar bukan saja siswa memiliki wawasan yang luas tentang lingkungan, tetapi lebih dari itu mereka mampu mengimplementasikan perilaku mereka sehari-hari yang berwawasan lingkungan.

Dalam kaitan dengan tujuan pembelajaran seharusnya perilaku seseorang dapat diukur apakah terjadi perubahan atau pengembangan perilaku sebagai hasil pembelajaran satu mata ajaran dalam waktu tertentu. Untuk itu diperlukan mekanisme penilaian (assessment) yang mampu mengukur perubahan tersebut. Perilaku yang aktif (overt content), dapat diamati secara langsung oleh peneliti yang kemudian memberi penilaian. Sementara perilaku yang pasif, tidak nyata dan tidak langsung terlihat (covert content), biasanya dilakukan melalui angket di mana orang yang ingin dinilai akan mengisi sendiri angket tersebut (self evaluation) (Lanyon, 1977: 144).

Dari pendapat-pendapat di atas dapat disimpulkan bahwa perilaku adalah suatu kegiatan memilih tindakan tertentu yang dipengaruhi oleh tujuan, dorongan (motif), faktor internal individu sebagai hasil interaksi dengan lingkungannya.

Chiras (1991: 3) mengemukakan bahwa lingkungan adalah segala sesuatu yang ada di sekitar kita yaitu udara, air, daratan, dan semua mahluk hidup yang menjadi penghuninya. Udara sangat mempengaruhi kehidupan mahluk hidup melalui kandungan berbagai gas dan partikel-partikel lainnya. Air merupakan sumber daya bagi semua mahluk hidup, sedangkan daratan merupakan habitat bagi manusia.

Menurut Odum (1971: 3), mahluk hidup dari yang bersel sederhana sampai yang kompleks dalam

\begin{tabular}{|l|l|l|l|}
\hline Volume XI & Nomor 02 & Maret 2010 & ISSN 1411-1829 \\
\hline
\end{tabular}


melakukan kegiatan untuk mempertahankan hidupnya pastilah mempunyai kemampuan beradaptasi dengan lingkungannya. Selain itu mereka akan berinteraksi antara satu dengan yang lain, membentuk rantai makanan dan jaring-jaring makanan.

Lingkungan menurut Miller (1986: 382), merupakan keseluruhan kondisi eksternal yang mempengaruhi kehidupan suatu organisme atau populasi. Miller juga menyatakan bahwa sumber daya alam merupakan suatu bentuk materi atau energi yang diperoleh dari lingkungan fisik untuk memenuhi kebutuhan manusia. Lingkungan juga merupakan suatu ruang tiga dimensi, di mana organisme merupakan salah satu bagiannya. Lingkungan bersifat dinamis dan berubah-ubah setiap saat. Jadi antara organisme dan lingkungan terjalin hubungan yang erat dan bersifat timbal balik. Tanpa lingkungan, organisme tidak mungkin ada, sebaliknya tanpa organisme maka lingkungan tidak akan berarti apa-apa. Di dalam lingkungan juga terdapat kumpulan berbagai faktor atau kondisi luar yang mempengaruhi benda-benda hidup dalam segala hal, baik mencakup manusia, hewan, tumbuhan, organisme, tanah, air, udara, dan lain-lain yang keseluruhannya digolongkan ke dalam materi dan satuannya disebut komponen. Keseluruhan unsur tersebut tidak terpisah satu dengan yang lainnya, melainkan memiliki pola hubungan tertentu yang bersifat tetap dan teratur serta merupakan suatu sistem hubungan timbal balik (interaksi) yang saling mempengaruhi.

Faktor-faktor lingkungan yang diperlukan untuk mendukung pembangunan yang berwawasan lingkungan, terdiri dari delapan prinsip yaitu: (1) terpeliharanya proses ekologi yang dianggapnya baik untuk dilakukan, (2) kejujuran, yang merupakan sikap dasar seseorang, (3) prinsip keadilan, menghendaki agar kita memperlakukan diri sendiri dan pihak lain sesuai dengan haknya masing-masing, (4) prinsip hormat, yang merupakan lawan dari kesewenangan dan ketidakpedulian terhadap pihak lain, (5) prinsip kesetiakawanan, yang bertitik tolak dari kesadaran etis bahwa agar kebutuhan dan kepentingan kita mendapat perhatian orang lain, (6) prinsip pengendalian diri, yang mengandung makna kesediaan mengekang diri untuk tidak larut dalam kenikmatan tanpa batas, (7) prinsip hemat, yang mengacu pada kesadaran bahwa kehidupan manusia akan terus berlangsung selama jangka waktu yang tidak bisa diperhitungkan secara pasti, dan (8) prinsip kasih sayang, bahwa setiap orang dituntut untuk menumpahkan kasih sayangnya tidak hanya pada anggota keluarga, kerabat, melainkan juga sampai pada semua unsur lingkungan hidup tempat ia melangsungkan kehidupan.

Banyak pengamat berargumentasi bahwa kepedulian ekologis akan mempersingkat kehidupan dan memperpincang tindakan ekologis, yang bahkan akan menjadi lebih buruk lagi jika diikuti sikap-sikap yang cenderung merusak lingkungan. Scumacher mengatakan bahwa kerusakan alam bukan akibat dari ilmu dan teknologi atau penelitian yang dilakukan para ilmuwan akan tetapi hal itu diakibatkan oleh perilaku dunia modern dengan sistem kepercayaan dan keyakinannya (Barrow, 1995: 56 - 65).

Perilaku seseorang terhadap alam semesta, dapat diungkapkan ke dalam delapan dasar keyakinan, yaitu : (1) manusia adalah sumber semua nilai (pandangan anthropocentrism), (2) alam itu ada untuk dimanfaatkan, (3) tujuan utama keberadaan manusia adalah untuk menghasilkan dan mengkonsumsi materi, di mana kesuksesan diukur dari kesejahteraan material, (4) sumber-sumber materi dan energi tak terbatas, sebab manusia dapat membuat hal itu tersedia dengan sendirinya, (5) produksi dan konsumsi barang-barang harus meningkat tanpa akhir, sebab kita memihak untuk terus menambah materi sebagai suatu standar hidup, (6) kita tak perlu menyesuaikan diri dengan lingkungan alam, karena manusia dapat membuat kembali alam tersebut sesuai dengan kebutuhannya melalui ilmu pengetahuan dan teknologi, (7) fungsi utama dari suatu negara adalah membantu individu dan perusahaan dalam mengeksploitasi lingkungan untuk meningkatkan kesejahteraannya, dan (8) orang yang ideal adalah orang yang sanggup membuat dirinya individualistis, yaitu orang yang memiliki sesuatu dengan tidak merugikan orang lain (Miller, 1986: 453).

Di lain pihak, banyak ahli lingkungan berpendapat bahwa seharusnya kita dapat mengadopsi pandangan kelangsungan bumi berdasarkan penempatan kembali delapan perilaku seseorang terhadap alam dengan petunjuk etis yang dapat dijabarkan sebagai berikut : (1) manusia bukan merupakan sumber segala nilai, (2) alam tidak sematamata hanya untuk manusia, tetapi juga untuk semua mahluk hidup, (3) tujuan utama manusia adalah untuk berbagi dan peduli terhadap sesamanya dan menyadari bahwa semua mahluk mempunyai hak untuk hidup tanpa tekanan atau kontrol dari manusia, (4) sumber materi dan energi bersifat terbatas dan oleh karenanya jangan dibuang-buang, (5) produksi dan konsumsi barang-barang harus dibatasi sehingga tidak membahayakan kelestarian sumber daya alam, (6) manusia sebagai bagian dari alam seharusnya bekerja dengan tidak melawan alam, (7) fungsi utama dari suatu negara adalah memberi pengarahan dan perencanaan jangka panjang, dan (8) manusia tidak dapat memperhitungkan segala akibat di masa yang akan datang atas manusia dan mahluk hidup lainnya. Semua tindakan di masa lalu, saat ini dan di masa yang akan datang akan memiliki akibat, di mana

\begin{tabular}{|l|c|c|c|}
\hline Volume XI & Nomor 02 & Maret 2010 & ISSN 1411-1829 \\
\hline
\end{tabular}


sebagian besar dari akibat itu tidak dapat diperkirakan (Miller, 1986: 454).

Akar penyebab krisis lingkungan bukan karena pertumbuhan penduduk atau pertumbuhan industri, juga bukan karena sistem ekonomi dan politik, melainkan karena nilai-nilai manusia yang mendorong keputusannya dalam berperilaku, khususnya keputusan yang kurang mendukung pelestarian alam semesta (Swan: 1974: 91 - 99).

Menurut Chiras (1985: 454), perilaku berwawasan lingkungan adalah perilaku atau perbuatan manusia yang secara sadar terhadap lingkungan dengan bertanggung jawab. Perilaku yang berwawasan lingkungan ini merupakan lawan dari mentalitas frontier.

Perilaku berwawasan lingkungan pada hakikatnya adalah ekspresi perasaan dan pikiran positif seseorang yang diwujudkan dalam bentuk perbuatan dalam rangka membina dan mewujudkan keseimbangan antara manusia dengan organisme lainnya. Perilaku berwawasan lingkungan berkaitan erat dengan kepercayaan dan nilai terhadap : (1) Penggunaan lingkungan alam, (2) Keprihatinan terhadap lingkungan, (3) Konservasi lingkungan dan sumber daya alam, (4) Kepercayaan terhadap ilmu dan teknologi serta (5) Kepedulian terhadap pertumbuhan ekonomi (Wiersma, 1986: 11).

Perilaku berwawasan lingkungan merupakan suatu kewajiban moral manusia terhadap alam yang berasal dari kewajiban kita terhadap sesama mahluk. Kita harus menaruh hormat kepada hak asasi setiap orang dan harus melindungi serta meningkatkan kesejahteraan manusia tetapi ia harus mengambil perilaku tertentu terhadap lingkungan alam dan apa saja yang menghuninya. Generasi yang akan datang mempunyai hak untuk menghayati kehidupan yang aman dan sehat secara fisik, sebagaimana halnya dengan generasi sekarang. Oleh karena itu setiap individu mempunyai kewajiban untuk tidak membiarkan lingkungan alam merosot mutunya, sehingga membahayakan kelangsungan dan kesejahteraan penghuninya di masa depan (Chiras, 1988: 454).

Perilaku yang berwawasan lingkungan merupakan perilaku yang dilahirkan dengan berbagai kegiatan yang mencerminkan apresiasi terhadap alam dan lingkungan sekitar. Siswa bisa melakukan eksplorasi lingkungan sekitarnya, di rumah maupun di sekolah, sehingga dia menaruh apresiasi yang baik terhadap lingkungannya. Kegiatan tersebut, misalnya menanam pohon-pohon, tidak memetik bunga dan mencabut pohon sembarangan, tidak membeli bahanbahan yang dibuat dari binatang-binatang yang dilindungi, menyebarkan pesan-pesan lingkungan untuk teman, dan membantu kelompok-kelompok pecinta alam setempat (Poniah, 1977: 28).

Menurut Chiras (1988: 454) bahwasanya kerusakan lingkungan alam adalah karena ulah manusia yang bermentalitas frontier, yang mempunyai ciri-ciri sebagai berikut : (1) berpandangan bahwa sumber kekayaan alam tidak terbatas untuk digunakan oleh semua manusia karena selalu ada dan tidak pernah habis, (2) berpandangan bahwa manusia bukan bagian dari alam, dan (3) berpandangan bahwa alam ada untuk dikuasai manusia dan digunakan untuk memenuhi kebutuhan hidupnya.

Sebaliknya Chiras juga menyatakan bahwa dalam kehidupan sehari-hari yang disebut dengan perilaku berwawasan lingkungan adalah perbuatan yang : (1) menggunakan sumber daya secara hemat dan melakukan konservasi, (2) menggunakan kembali (reuse) dan mendaur ulang (recycling) bahan-bahan bekas pakai, (3) mengelola lingkungan alam, dan (4) mengendalikan pertumbuhan penduduk.

Baron \& Byrne (1991: 541) menyatakan bahwa perilaku berwawasan lingkungan seperti (1) memperhatikan masalah-masalah lingkungan lokal, seperti polusi air, polusi tanah, polusi udara, (2) mendukung peraturan-peraturan lingkungan seperti pembatasan pemakaian pestisida, pembuangan sampah, dan (3) berperilaku ekologis, seperti antara lain: menggunakan sabun yang kadar fosfatnya rendah, menghemat energi listrik.

Berdasarkan uraian di atas dapat disimpulkan bahwa secara konseptual yang dimaksud dengan perilaku berwawasan lingkungan adalah keseluruhan perbuatan atau tindakan siswa dalam pemakaian sumber daya secara hemat, menjaga kebersihan, memelihara keindahan sehingga terpelihara kelestarian lingkungan.

\section{Pendidikan Lingkungan Hidup}

Pendidikan Lingkungan Hidup menurut Konvensi UNESCO (1977: 26) di Tbilisi pada tahun 1977, adalah proses yang bertujuan untuk menciptakan suatu masyarakat yang memiliki kepedulian terhadap lingkungan serta memiliki pengetahuan, keinginan dan kemampuan untuk bekerja, baik secara perorangan maupun bersama dalam memberikan solusi terhadap permasalahan yang ada dan juga untuk menghindari timbulnya masalah lingkungan yang baru.

Hal ini berarti bahwa sasaran Pendidikan Lingkungan Hidup tidak hanya tertuju pada pemahaman kognitif semata, tetapi juga pemahaman tentang keselarasan hubungan antar manusia, hewan, tumbuhan dan benda tak hidup, serta adanya upaya

\section{\begin{tabular}{|l|l|l|l|}
\hline Volume XI & Nomor 02 & Maret 2010 & ISSN 1411-1829 \\
\hline
\end{tabular}}


peningkatan perilaku dan nilai positif terhadap masalah lingkungan secara keseluruhan.

Pendidikan Lingkungan Hidup mempunyai efek yang lebih baik jika diberikan sejak anak berusia dini yaitu dimulai dari masa kanak-kanak yaitu dapat dimulai dari lingkungan keluarga dan sekolah. Menurut UNESCO - UNEP (1987) terdapat enam kategori sasaran Pendidikan Lingkungan Hidup, yaitu (1) Awareness, yaitu membantu seseorang memperoleh kesadaran dan sensitivitas terhadap lingkungan keseluruhan dan masalah-masalahnya; (2) Knowledge, yaitu membantu seseorang untuk mendapatkan berbagai pengetahuan dan pengertian dasar tentang lingkungan dan masalah-masalah yang terkait; (3) Attitude, yaitu membantu seseorang memperoleh nilai-nilai sosial sehingga membentuk perilakunya untuk berpartisipasi dalam perbaikan lingkungan; (4) Skills, yaitu membantu seseorang memperoleh keterampilan untuk mengatasi masalah lingkungan; (5) Evaluation ability, yaitu membantu seseorang untuk menilai dan membuat program pendidikan yang berhubungan dengan ekologi, politik, ekonomi, sosial; (6) Participation, yaitu membantu seseorang untuk mempunyai perasaan empati untuk aktif bekerja dalam mengatasi masalah lingkungan (UNESCO, 1977: 28).

Paket materi UNESCO di atas kemudian diadopsi oleh Masahisa Sato dan dikelompokkan menjadi 4 paket materi strategi Pendidikan Lingkungan Hidup yang bermanfaat untuk mendapatkan awareness, knowledge, attitudes, skills and participation tentang lingkungan (Sato, 2000: 47 - 53). Paket materi tersebut adalah : (1) In / thought the environment, di mana peserta didik diajak ke lapangan dan melihat kenyataan yang ada, sehingga diharapkan mereka akan mendapatkan kesan tentang alam atau lingkungan dan memperoleh suatu pengalaman (experience) yang berharga; (2) About the environment, di mana peserta didik diberikan pengertian (understanding) sehingga menjadi peduli (concern) terhadap masalah-masalah lingkungan; (3) For the environment, di mana peserta didik melakukan kegiatan yang berhubungan langsung dengan praktek pelestarian lingkungan sehingga diharapkan akan terjadi perubahan perilaku peserta didik ke arah perilaku berwawasan lingkungan; (4) Information of environment, diperlukan agar dapat mewujudkan lingkungan hijau di masa depan. Untuk menunjang kegiatan tersebut, dibutuhkan sarana penunjang, di antaranya pusat kunjungan, taman atau hutan yang berwawasan ekologi, tempat pengolahan limbah, tempat pengolahan sampah kota, kawasan ramah lingkungan, dan lain-lain.

Pengenalan program Pendidikan Lingkungan Hidup di Indonesia telah dirintis sejak tahun 1979, dan bahkan implementasi program tersebut di sekolah (SD, SLTP, dan SMU) secara implisit sudah diperkenalkan melalui kurikulum 1984.

Secara umum Pendidikan Lingkungan Hidup di sekolah bertujuan membentuk kesadaran, nilai-nilai, sikap dan ketrampilan terhadap keselarasan lingkungan. Secara lebih khusus Pendidikan Lingkungan Hidup untuk siswa SD adalah agar siswa memiliki pengetahuan, sikap dan tingkah laku rasional dan bertanggungjawab terhadap masalah lingkungan hidup sesuai dengan kemampuan yang diperolehnya.

Menurut Yusuf (2000: 76), Pendidikan Lingkungan Hidup adalah pendidikan yang menggunakan pendekatan belajar across the curriculum, artinya belajar yang membantu siswa untuk memahami lingkungan hidup dengan tujuan mereka akan memiliki kepedulian untuk menjaga dan melestarikan lingkungan dengan bekerja secara rukun dan aman. Oleh karenanya Pendidikan Lingkungan Hidup didasarkan pada keempat pilar pendidikan, yaitu (1) pendidikan untuk mengetahui dan memahami lingkungan hidup dengan segala aspeknya (learning to know), (2) pendidikan untuk menanamkan sikap, kemampuan dan ketrampilan dalam melestarikan lingkungan (learning to do), (3) pendidikan untuk menanamkan cara hidup bersama di bumi yang harus diamankan kelestariannya bagi generasi yang akan datang (learning to live together), dan (4) pendidikan untuk menanamkan keyakinan yang mendalam bahwa manusia merupakan bagian dari alam, bahwa manusia merupakan teman dan bukan lawan alam, serta dalam kehidupannya harus bertindak secara ramah dan bijaksana memperlakukan alam (learning to be).

Dari uraian di atas dapat disimpulkan bahwa Pendidikan Lingkungan Hidup adalah suatu proses pembelajaran yang bertujuan agar peserta didik memiliki suatu kemampuan untuk memahami permasalahan lingkungan hidup dan mampu memecahkan masalah yang dihadapi sehingga diharapkan dia akan memiliki perilaku yang bertanggung jawab di lingkungannya sendiri.

\section{Paket Materi Pembelajaran Inkuiri}

Paket materi merupakan seperangkat pelajaran yang disusun secara sistematis dan menampilkan kompetensi yang akan dicapai siswa dalam kegiatan pembelajaran. Dick\&Carey (1996: 186) menyatakan bahwa paket materi berisikan informasi yang dapat berupa tulisan atau media yang digunakan oleh siswa untuk mencapai tujuan pembelajaran.

Romiszowski (1986: 22) berpendapat bahwa paket materi hendaknya mempertimbangan empat aspek, yaitu: (1) aspek akademik, paket materi hendaknya dapat memfasilitasi siswa untuk

\begin{tabular}{|l|c|c|c|}
\hline Volume XI & Nomor 02 & Maret 2010 & ISSN 1411-1829 \\
\hline
\end{tabular}


mengembangkan kemampuan akademik yang berorientasi pada ranah kognitif, afektif, dan psikomotorik; (2) aspek sosial, paket materi diharapkan dapat memberikan kemampuan pada peserta didik untuk berkomunikasi secara sosial kepada seluruh lapisan masyarakat di manapun ia berada; (3) aspek rekreasi, paket materi harus menarik, isinya tidak membuat siswa merasa bosan dalam mempelajarinya; dan (4) aspek pengembangan pribadi, paket materi dapat memberi kesan bagi penggunanya dan memenuhi baik kebutuhan akademik, sosial, rekreasi, maupun kebutuhan individu.

Pembelajaran pada hakikatnya adalah proses interaksi antara peserta didik dengan lingkungannya, sehingga terjadi perubahan perilaku ke arah yang baik. Dalam interaksi tersebut banyak sekali faktor yang mempengaruhinya, baik faktor internal yang datang dari dalam diri individu, maupun faktor eksternal yang datang dari lingkungannya. Dalam pembelajaran tugas guru yang paling utama adalah mengkondisikan lingkungan agar menunjang terjadinya perubahan perilaku bagi peserta didik. Umumnya pelaksanaan pembelajaran mencakup tiga hal : pre tes, proses, dan pos tes.

Gagne (1975: 5) berpendapat bahwa pembelajaran merupakan suatu rangkaian peristiwa yang dapat mempengaruhi siswa sehingga terjadilah proses belajar. Rangkaian peristiwa tersebut dapat digerakkan oleh pengajar sehingga disebut sebagai pengajaran, tetapi dapat juga digerakkan oleh siswa sendiri dengan menggunakan buku, gambar dari media televisi, atau kombinasi dari berbagai media. Rangkaian peristiwa baik yang digerakkan oleh guru / pengajar maupun oleh siswa sendiri haruslah terencana secara sistematik sehingga dapat disebut sebagai kegiatan instruksional. Kegiatan tersebut mempunyai tujuan agar terujud efisiensi dan efektivitas proses belajar yang dilakukan peserta didik.

Dick dan Carey (1996: 186) berpendapat bahwa pembelajaran adalah suatu kegiatan yang menyeluruh untuk mencapai tujuan pembelajaran, yang terdiri dari lima komponen yaitu : (1) aktivitas pra instruksional yang bertujuan untuk memotivasi siswa, penyampaian tujuan baik secara verbal ataupun tertulis, serta memberikan informasi prasyarat yang harus dimiliki siswa sebelum mengikuti pelajaran; (2) penyampaian informasi yang berfokus pada isi, urutan materi pelajaran dan tahap pengajaran yang harus dilaksanakan baik oleh guru maupun siswa dalam mencapai tujuan pengajaran; (3) partisipasi siswa dalam bentuk latihan dan pemberian umpan balik; (4) pemberian tes untuk mengontrol pencapaian tujuan pembelajaran; dan (5) tindak lanjut dalam bentuk pengayaan dan remedial.

Gagne dan Briggs (1979: 19) juga mengemukakan ada sembilan langkah dalam pembelajaran yang terdiri dari (1) pemberian motivasi, (2) menguraikan tujuan pembelajaran, (3) mengingatkan kompetensi prasyarat, (4) memberikan stimulus, (5) memberikan petunjuk belajar, (6) menggali kemampuan siswa, (7) memberi umpan balik, (8) memberi penilaian atas kemampuan siswa, dan (9) menyimpulkan hasil yang telah dicapai.

Pembelajaran juga merupakan perpaduan dari (1) urutan kegiatan pembelajaran, (2) metode pembelajaran, yaitu cara pengorganisasian materi pengajaran dan siswa, (3) media pembelajaran, yaitu peralatan dan bahan, (4) waktu yang diperlukan dalam proses pembelajaran (Suparman, 1992: 157). Strategi instruksional dapat pula disebut sebagai cara yang sistimatik dalam mengkomunikasikan isi pelajaran kepada siswa untuk mencapai tujuan pembelajaran tertentu.

Inkuiri (inquiry) pada dasarnya adalah cara menyadari apa yang telah dialami. Oleh karena itu inkuiri menuntut peserta didik atau siswa untuk berpikir.

Pembelajaran inkuiri menurut Massialas and Cox (1966: 310), pada dasarnya mempunyai beberapa karakteristik : (1) Orientation, (2) Hypothesis, (3) Definition, (4) Exploration, (5) Evidencing, dan (6) Generalization. Hal tersebut merupakan suatu cara dalam menyadari apa yang telah dialami. Oleh karena itu inkuiri menuntut peserta didik atau siswa untuk berpikir. Metode ini menempatkan peserta didik pada situasi yang melibatkan mereka dalam kegiatan intelektual (Mulyasa, 2002: 234). Hal ini menuntut seorang siswa memproses pengalaman belajar menjadi sesuatu yang bermakna dalam kehidupan nyata.

Pembelajaran inkuiri akhir-akhir ini merupakan salah satu program yang sering dipakai untuk mengembangkan paket materi pembelajaran di SD (Essler, 1996: 107). Pada pembelajaran inkuiri lebih menekankan pada keterlibatan siswa dalam proses pembelajaran yang aktif melalui kegiatan-kegiatan yang berorientasi pada penemuan (discovery), dengan pemikiran bahwa siswa akan termotivasi lebih baik jika ia terlibat secara langsung.

Pembelajaran inkuiri didefinisikan oleh Piaget sebagai pembelajaran yang mempersiapkan situasi bagi anak untuk melakukan eksperimen atau percobaan sendiri. Dalam arti yang lebih luas, anak ingin melihat apa yang terjadi, ingin melakukan sesuatu, ingin mencari jawaban atas pertanyaan sendiri, ingin menghubungkan penemuan yang satu dengan penemuan yang lain, dan membandingkan apa

\section{\begin{tabular}{|l|l|l|l|}
\hline Volume XI & Nomor 02 & Maret 2010 & ISSN 1411-1829 \\
\hline
\end{tabular}}


yang dia temukan dengan apa yang ditemukan orang lain (Sund, 1973: 80).

Pembelajaran inkuiri merupakan pendekatan mengajar yang berusaha meletakkan dasar dan mengembangkan cara berpikir ilmiah. Dalam pembelajaran inkuiri siswa lebih banyak belajar sendiri dan mengembangkan kekreatifan dalam pemecahan masalah, sedangkan guru berperan sebagai fasilitator saja.

Menurut Kuslan \& Stone (1968: 75), pembelajaran inkuiri dikatakan sebagai pengajaran di mana guru dan siswa mempelajari peristiwa dan gejala alam dengan pendekatan dan jiwa ilmuwan.

Pembelajaran inkuiri menurut Conny Semiawan (1993: 54) memanfaatkan sumber-sumber belajar yang ada di lingkungan sekolah dan sekitarnya termasuk lingkungan tempat tinggal siswa serta mengaitkan materi pelajaran yang sedang dipelajari dengan benda atau fenomena dalam kehidupan sehari-hari. Hal tersebut berangkat dari asumsi bahwa dengan mempergunakan sumber-sumber belajar yang ada di lingkungan siswa maka siswa akan menjadi lebih tertarik sebab seolah-olah mereka sedang bermain dengan lingkungan mereka setiap hari dan sekaligus meningkatkan pemahaman mereka terhadap lingkungannya.

Dalam inkuiri model Suchman, tahapan belajar meliputi lima fase, seperti tampak pada tabel di bawah ini (Joyce\&Weil, 1980: 66).

\section{Tabel 1. Inkuiri menurut Suchman}

\begin{tabular}{|l|l|l|l|}
\hline No & Fase & \multicolumn{1}{|c|}{ Keterangan } & \multicolumn{1}{|c|}{ Kegiatan } \\
\hline 1 & Satu & $\begin{array}{l}\text { Pengidentifikasian } \\
\text { Masalah }\end{array}$ & $\begin{array}{l}\text { a. Menjelaskan } \\
\text { prosedur } \\
\text { penelitian } \\
\text { b. Menyajikan } \\
\text { situasi yang ada }\end{array}$ \\
\hline 2 & Dua & Pengumpulan data & $\begin{array}{l}\text { a. Memeriksa } \\
\text { hakikat obyek } \\
\text { b. Memeriksa } \\
\text { timbulnya } \\
\text { masalah }\end{array}$ \\
\hline 3 & Tiga & Eksperimen & $\begin{array}{l}\text { Menentukan } \\
\text { hipotesis dan } \\
\text { hubungan } \\
\text { kausal. }\end{array}$ \\
\hline 4 & Empat & $\begin{array}{l}\text { Perumusan dan } \\
\text { Pengkajian }\end{array}$ & $\begin{array}{l}\text { Merumuskan } \\
\text { cara-cara untuk } \\
\text { menjelaskan apa } \\
\text { yang dilakukan } \\
\text { sebelumnya. }\end{array}$ \\
\hline 5 & Lima & $\begin{array}{l}\text { Menganalisa } \\
\text { strategi }\end{array}$ \\
\hline
\end{tabular}

\begin{tabular}{|l|l|l|}
\hline & & $\begin{array}{l}\text { penelitian untuk } \\
\text { mengembangkan } \\
\text { prosedur yang } \\
\text { lebih efektif. }\end{array}$ \\
\hline
\end{tabular}

Kekhususan model ini adalah guru harus membangkitkan motivasi siswa, sehingga siswa tergerak untuk mengumpulkan data lewat proses simulasi dengan tanya jawab yang berkesinambungan atau melakukan eksperimen untuk memecahkan masalah dan menghasilkan suatu formulasi.

Dalam pembelajaran inkuiri ini ada dua perbedaan, yaitu inkuiri terbimbing (guided inquiry) dan inkuiri bebas (free inquiry) (Michael, 1979: 100).

Untuk tingkat Sekolah Dasar, pembelajaran inkuiri yang digunakan adalah inkuiri terbimbing. Hal ini disesuaikan dengan tingkat perkembangan intelektual siswa SD. Perkembangan kognitif siswa SD umumnya berada pada stadium operasional konkrit. Cara berpikir anak dalam stadium ini menggunakan cara berpikir logis, tetapi belum mampu menerapkan secara logis masalah - masalah abstrak (Piaget, 1973: 80).

Tahap operasional konkrit merupakan tahap transisi antara tahap pra operasional dengan tahap berpikir formal (logika). Selama tahap operasional konkrit, perhatian anak mengarah kepada hal logis yang sangat cepat. Tahap ini tidak lama dan didominasi oleh persepsi, sehingga anak sudah dapat memecahkan masalah dan mampu bertahan dengan pengalamannya.

Pembelajaran inkuiri dapat diterapkan dalam Pendidikan Lingkungan Hidup karena (1) Rasa ingin tahu anak umumnya tinggi. Dengan memberi anak kegiatan maka merupakan kesempatan bagi anak untuk memperhatikan, mengamati atau melakukan sesuatu dengan menggunakan seluruh inderanya, (2) Anak-anak suka bergerak, berjalan-jalan, memanjat dan lain-lain. Hal ini tentunya memberikan kesempatan padanya untuk menyalurkan energi tersebut dalam kegiatan yang terarah, dengan mempertimbangkan keamanannya, (3) Daya konsentrasi anak masih terbatas walaupun perhatiannya luas sehingga anak cenderung menjadi kurang sabar dan ingin cepat-cepat pindah ke masalah berikutnya sehingga kegiatan sebaiknya dirancang berkelanjutan satu sama lain dan menarik (Nirarita, 1999: 25 - 28).

Pembelajaran inkuiri menurut Sudirman, mempunyai kelebihan dan kekurangan (Soekamto, 1997: 94). Kelebihannya adalah : (1) pembelajaran berubah dari penyajian informasi oleh guru menjadi proses pengolahan informasi oleh siswa, (2) pengajaran berubah dari yang terpusat pada guru 
(teacher centered) menjadi lebih terpusat pada siswa (student centered), (3) dapat memperpanjang proses ingatan atau konsep yang telah dipahami siswa lebih lama, (4) dapat memungkinkan siswa belajar dengan memanfaatkan berbagai sumber belajar, (5) dapat mengembangkan bakat dan kecakapan siswa, (6) dapat memperkaya dan mendalami materi yang dipelajari, (7) menghindarkan siswa belajar dengan hafalan, dan (8) memberikan waktu kepada siswa untuk mengasimilasi dan mengakomodasi informasi sehingga menjadi bermakna baginya.

Adapun kelemahan pembelajaran inkuiri ini adalah : (1) memerlukan perubahan kebiasaan belajar siswa yaitu dari menerima informasi menjadi mengolah informasi, (2) menuntut guru untuk mengubah cara mengajarnya, dari seorang penyaji menjadi fasilitator dalam membimbing siswa belajar, (3) memberikan kebebasan siswa dalam belajar, (4) memerlukan penyediaan berbagai sumber belajar dan fasilitas yang memadai bagi siswa, dan (5) bila tidak menarik dalam kegiatannya, akan menimbulkan kebosanan pada siswa.

Untuk menarik minat siswa diperlukan upaya penggunaan sumber belajar yang ada di lingkungan sekolah dan sekitarnya termasuk lingkungan rumah siswa serta mengaitkan materi yang diajarkan dengan benda atau fenomena dalam kehidupan sehari-hari. Hal ini kemudian disajikan dalam bentuk masalah dan disodorkan melalui paket materi pembelajaran inkuri. Paket materi pembelajaran semacam ini merupakan pengembangan dari inkuiri terpimpin.

Sumber belajar yang terdapat di lingkungan siswa yang dapat dimanfaatkan dalam proses pembelajaran, misalnya (1) Lingkungan fisik di sekitar sekolah siswa, (2) Masyarakat di sekitar sekolah siswa, (3) Bahan yang tidak terpakai dan barang bekas berupa sampah, (4) Peristiwa alam dan peristiwa yang terjadi di masyarakat yang dapat menarik perhatian siswa (Semiawan, 1992: 195).

Dengan demikian berdasarkan kajian teori-teori di atas, dapat disimpulkan bahwa pembelajaran inkuiri adalah pembelajaran yang melukiskan prosedur yang sistematis dengan memanfaatkan sumber-sumber belajar di lingkungan siswa, yang mempersiapkan anak melakukan eksperimen sendiri dan mengaitkan materi pelajaran dengan fenomena kehidupan seharihari.

\section{Tinjauan Teori Belajar terhadap Paket Materi Pembelajaran Inkuiri}

Teori belajar adalah satuan prinsip terorganisir yang menjelaskan bagaimana individu memperoleh pengetahuan dan dapat digunakan sebagai pedoman dalam memilih sarana instruksional, teknik dan strategi pembelajaran yang dibutuhkan oleh siswa.

\section{Teori Perkembangan Kognitif}

Dari teori perkembangan kognitif Piaget ini maka siswa SD yang umumnya berusia 7 - 12 tahun adalah mereka yang berada pada fase operasi konkrit. Oleh karena itu ciri pokok perkembangan kognitif peserta didik kelas 5 SD sangat bergantung pada rujukan atau hal-hal yang konkrit.

Piaget mengemukakan bahwa perkembangan kognitif itu sendiri merupakan suatu usaha penyesuaian diri kepada lingkungan melalui proses asimilasi dan akomodasi. Asimilasi adalah suatu tindakan pasif dalam membangun pengetahuan utama yang melibatkan penafsiran peristiwa dalam hubungannya dengan struktur kognitif yang ada. Akomodasi merupakan suatu upaya untuk mengkontruksi pengetahuan baru yang mengacu pada perubahan struktur kognitif yang disebabkan oleh lingkungan. Dengan demikian implementasi teori ini mengakui bahwa faktor lingkungan mempengaruhi perkembangan kognitif anak karena adanya suatu proses interaktif secara internal dalam membentuk konsep dan membangun makna, yang kemudian mendorongnya ke arah pemecahan masalah abstrak serta pemikiran konseptual yang sudah dilakukannya.

Bertitik tolak pada teori perkembangan kognitif tersebut di atas, maka dapat dinyatakan bahwa bila paket materi Pendidikan Lingkungan Hidup mengacu pada pendekatan konkrit di sekitar lingkungan siswa baik di rumah maupun di sekolah, akan membantu siswa dalam memahami dan menyerap materi yang diberikan.

\section{Teori Belajar Kognitif}

Teori belajar kognitif (Bruner, 1971:21) memiliki asumsi bahwa siswa telah mempunyai pengalaman dan pengetahuan dalam dirinya yang tertata dalam bentuk skema. Skema tersebut terbentuk dari informasi yang diperoleh secara empiris terhadap apa yang ada dan ditemui di lingkungannya. Sehubungan dengan itu maka teori belajar kognitif menyatakan bahwa proses akan berjalan baik bila paket materi yang baru dapat beradaptasi secara tepat dengan struktur kognitif siswa. Teori belajar kognitif melihat siswa mempunyai peran aktif yang lebih pro aktif dalam belajar sendiri. Proses belajar berlangsung pada skema di mana siswa mengorganisir lingkungan yang dialaminya. Oleh karena itu siswa setidaknya harus mempunyai pengetahuan dasar (prior knowledge) tentang pokok materi yang diajarkan. Dalam hal ini paket materi yang diberikan hendaknya berhubungan dengan apa yang mereka telah ketahui. Atas dasar itu maka paket materi harus diarahkan

\begin{tabular}{|l|l|l|l|}
\hline Volume XI & Nomor 02 & Maret 2010 & ISSN 1411-1829 \\
\hline
\end{tabular}


dengan apa yang benar-benar telah diketahui atau setidaknya pernah diketahui.

Disebabkan oleh hal di atas apabila materi Pendidikan Lingkungan Hidup bersumber pada kenyataan yang ada di lingkungan peserta didik dalam suatu proses belajar, berarti kita memulai belajar dengan apa yang sudah diketahui oleh peserta didik. Penggunaan sumber belajar yang ada di sekitar lingkungan siswa akan memfasilitasi siswa untuk lebih memahami materi yang dipelajari.

Dengan demikian, dapat disimpulkan bahwa lingkungan peserta siswa juga merupakan salah satu sumber paket materi yang dapat dimanfaatkan dalam proses pembelajaran Pendidikan Lingkungan Hidup. Hal ini akan memfasilitasi siswa dalam proses pembelajaran yang dilakukan karena materi yang disajikan adalah sesuai dengan skemata (pengalaman) yang dimilikinya, sehingga ia akan mampu beradaptasi dengan pengetahuan yang baru. Di samping itu, hal ini secara tidak langsung juga memberikan pengalaman praktis dan konkret baginya terhadap hal-hal yang dipelajarinya. Sedangkan bagi guru sendiri hal ini akan sangat membantunya dalam mengembangkan atau mengarahkan siswa pada tujuan pembelajaran yang ingin dicapai, terutama pada siswa SD yang masih dalam fase operasi konkret. Penggunaan paket materi memungkinkan terbukanya peluang bagi siswa untuk bertindak lebih aktif serta dapat berinteraksi dengan materi tersebut. Hal ini dengan sendirinya akan mendukung proses pembelajaran yang dilaksanakan dan dapat dibenarkan secara teori. Piaget mengemukakan bahwa paket materi haruslah: (1) berpusat pada anak; (2) sesuai dengan fase perkembangan anak; (3) memungkinkan anak berinteraksi dengan paket materi; (4) memungkinkan anak berinteraksi secara sosial; dan (5) menaksir kebutuhan belajar melalui pengamatan secara http://www.sk.com.br/skpiaget.html 2004).

\section{Kerangka Konseptual Model Paket Materi Pembelajaran Inkuiri}

Yang dimaksud model dalam penelitian ini menurut Bruce Joyce\&Marsha Weil (1996: 1) adalah kerangka konseptual yang digunakan sebagai pedoman dalam melakukan suatu kegiatan. Dalam pengertian lain, model diartikan sebagai sebuah rencana atau petunjuk yang dapat digunakan untuk membentuk kurikulum (dalam pembelajaran jangka panjang), untuk membentuk paket materi dan memberikan petunjuk di dalam kelas ataupun situasi yang lain.
Pada tahap awal penelitian ini dilakukan suatu observasi di sekolah tentang perilaku berwawasan lingkungan pada siswa. Observasi ini dilakukan dengan teliti, sehingga dilihat adanya suatu kesenjangan. Ini tentu merupakan suatu masalah, karena pada masa sekarang ini perilaku berwawasan lingkungan sangat memegang peranan dalam kelangsungan kehidupan universal. Untuk mengatasi masalah ini ada banyak alternatif tindakan yang sudah diambil. Akan tetapi tentu menjadi suatu keinginan yang baik apabila dapat diambil suatu tindakan yang memberikan efek lebih signifikan dalam peningkatan perilaku berwawasan lingkungan.

Untuk mengambil tindakan-tindakan yang lebih efektif maka dikajilah teori-teori pembelajaran yang telah dibuktikan dapat untuk meningkatkan hasil belajar siswa.

Pendidikan merupakan salah satu pilar yang memungkinkan terjadinya perubahan sikap dan perilaku manusia. Upaya pendidikan yang dilakukan pastilah tidak terlepas dari suatu paket materi yang efektif untuk mencapai suatu tujuan tertentu.

Dari teori belajar dinyatakan bahwa proses pembelajaran yang dimulai dengan materi yang sudah dikenal siswa akan memudahkan proses adaptasi siswa dengan struktur kognitif yang telah dimiliki siswa.

Dari teori-teori yang telah dikemukakan serta upaya yang ingin dicapai, maka pengembangan paket materi inkuiri dalam Pendidikan Lingkungan Hidup merupakan salah satu alternatif yang diharapkan sesuai untuk meningkatkan perilaku berwawasan lingkungan siswa SD. Hal ini dikarenakan dalam pengembangan paket materi inkuiri, siswa dipersiapkan untuk melakukan eksperimen sendiri dan mengaitkan paket materi Pendidikan Lingkungan Hidup dengan memanfaatkan sumber-sumber belajar di lingkungan siswa sehingga pengetahuannya semakin bertambah. Dengan semakin bertambahnya pengetahuan siswa, maka diharapkan sikapnya menjadi semakin positif yang kemudian akan mengarahkannya untuk berperilaku yang berwawasan lingkungan. Oleh karena itu penelusuran kebutuhan siswa dalam pembelajaran Pendidikan Lingkungan Hidup merupakan langkah awal yang perlu dilakukan, sehingga paket materi yang diberikan akan memiliki kesesuaian dengan kebutuhan siswa dibandingkan paket materi yang menggunakan bahan-bahan pembelajaran yang lebih bersifat umum.

Oleh karena itu sebelum lebih luasnya paket materi Pendidikan Lingkungan Hidup dapat dilaksanakan, maka dipandang perlu untuk melakukan suatu penelitian tentang penerapan paket materi Pendidikan Lingkungan Hidup ini pada tingkat satuan pendidikan yang ada.

\begin{tabular}{|l|l|l|l|}
\hline Volume XI & Nomor 02 & Maret 2010 & ISSN 1411-1829 \\
\hline
\end{tabular}


Apabila kelak hasil penelitian ini dapat membuktikan adanya peningkatan perilaku berwawasan lingkungan pada siswa SD, maka paket materi yang diusulkan dapat diterapkan secara luas.

Uji coba ini dilakukan pada satuan pendidikan SD khususnya kelas V, dan penelitian ini dilakukan dengan metode penelitian dan pengembangan (R\&D).

Titik awal yang penting bagi penelitian ini adalah ditemukannya kebutuhan pembelajaran Pendidikan Lingkungan Hidup. Hal ini didapat dari kompilasi dari (1) tujuan pendidikan lingkungan, (2) kurikulum yang berlaku, dan (3) kumpulan informasi tentang situasi yang ada, yaitu dari situasi para siswa, teori dan pola belajar yang dilaksanakan, dan sumbersumber belajar yang ada di lingkungan siswa.

Berdasarkan kebutuhan ini maka dibuatlah suatu rancangan paket materi pembelajaran inkuiri dalam Pendidikan Lingkungan Hidup.

Menurut Silber (dalam Gustafon, 1981: 2) pengembangan paket materi adalah suatu pendekatan sistematis untuk mendesain, memproduksi, mengevaluasi, dan memanfaatkan sistem pembelajaran yang utuh, termasuk kesesuaian semua komponen dan pola-pola manajemen yang berlaku. Pengembangan paket materi merupakan suatu proses untuk meningkatkan kualitas pembelajaran guna mencapai hasil belajar yang lebih baik lagi. Oleh karena itu, pengembangan paket materi pada dasarnya tidak dapat mengabaikan komponen-komponen yang ada dalam suatu sistem pembelajaran, seperti tujuan pembelajaran, ketersediaan bahan dan alat yang akan digunakan, serta cara-cara untuk mengevaluasi hasil belajar, di samping kebijakan-kebijakan yang berlaku dalam proses itu sendiri, seperti kurikulum yang digunakan.
Penyampaian materi Pendidikan Lingkungan Hidup dibutuhkan kreativitas sehingga peserta didik menemukan langsung apa saja yang ada di lingkungannya, baik itu flora, fauna, maupun masalah yang berhubungan dengan lingkungan di sekitarnya. Pendidikan Lingkungan Hidup akan lebih efektif bila disampaikan jika siswa berkesempatan bergaul dengan lingkungannya. Itu sebabnya berbagai upaya dikembangkan agar paket materi Pendidikan Lingkungan Hidup disesuaikan dengan lingkungan dan masalah yang menjadi pengalaman yang ada di sekitar siswa.

Paket materi inkuiri dalam Pendidikan Lingkungan Hidup adalah penuntunan siswa agar sampai pada keyakinan adanya masalah-masalah atas obyek-obyek lingkungan hidup yaitu udara, air, energi dan sampah. Selanjutnya dengan melakukan percobaan para siswa akan menentukan hipotesis dan mencari hubungan kausal yang pada akhirnya menuntun siswa untuk memecahkan masalah lingkungan dan menghasilkan suatu formulasi.

Rancangan ini memerlukan sejumlah tahapan uji coba sedemikian rupa untuk mendapatkan validasinya.

Apabila sudah didapatkan suatu peningkatan perilaku yang signifikan maka paket materi ini menjadi sahih (valid) untuk diangkat menjadi sebuah paket materi pembelajaran inkuiri yang dapat dipakai untuk tujuan peningkatan perilaku berwawasan lingkungan siswa SD.

Berdasarkan kerangka berpikir yang dikemukakan di atas, maka secara konseptual model pengembangan paket materi inkuiri mengacu pada desain instruksional Dick \& Carey (1996:186) adalah sebagai berikut :

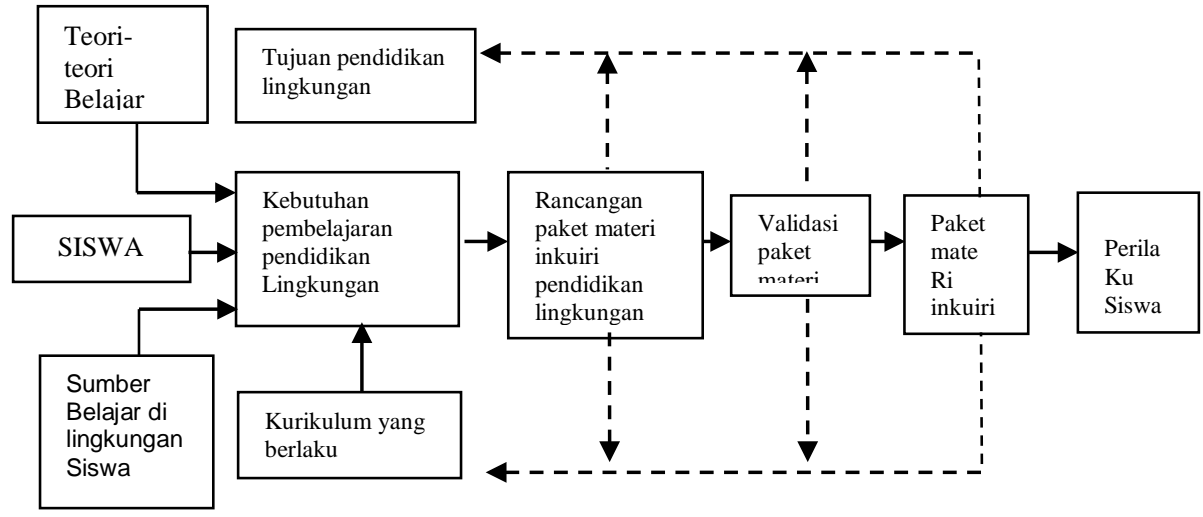

Gambar 1: Bagan Pengembangan Paket Materi Pembelajaran Inkuiri dalam Pendidikan Lingkungan Hidup

\begin{tabular}{|l|c|c|c|}
\hline Volume XI & Nomor 02 & Maret 2010 & ISSN 1411-1829 \\
\hline
\end{tabular}




\section{METODOLOGI PENELITIAN}

Penelitian ini bertujuan untuk mengembangkan paket materi pembelajaran inkuiri dalam Pendidikan Lingkungan Hidup yang ingin dilihat efektivitasnya dalam meningkatkan perilaku berwawasan lingkungan siswa.

Penelitian ini dilakukan terhadap siswa Sekolah Dasar kelas V. Adapun pertimbangan ini didasarkan, pada tingkatan ini anak telah berumur 11 tahun dan dia telah berada dalam stadium operasional formal menurut teori Piaget (Monks, 1999: 223). Anak dalam fase ini akan memikirkan dulu secara teoretik, kemudian menganalisis masalahnya dengan penyelesaian berbagai hipotesis yang mungkin ada. Anak kemudian dapat membuat pendapat-pendapat tertentu yang juga disebut proposisi-proposisi, dan mencari hubungan antara proposisi yang berbeda-beda tadi.

Waktu yang dibutuhkan untuk penelitian ini dari bulan Juli 2004 sampai Agustus 2005, yang dimulai dari perencanaan penelitian sampai analisis data. Tempat penelitian dilakukan di SD Rawamangun di Jakarta Timur, meliputi 3 SDN di Rawamangun yaitu SDN 01 Rawamangun, SDN 05 Rawamangun dan SDN 07 Rawamangun.

Populasi sebagai unit analisis pada penelitian ini adalah siswa SD kelas V di DKI Jakarta. Namun mengingat keterbatasan tenaga, waktu dan biaya, maka digunakan teknik sampel sebagai populasi terjangkau. Pemilihan SDN 01 Pagi Rawamangun ditentukan secara purposive sampling, kemudian dipilih 25 siswa dari 1 kelas sebagai sampel yang diberi perlakuan dan 25 siswa dari kelas yang sama sebagai kontrol dalam uji coba ke satu. Selanjutnya dari SDN 05 Pagi Rawamangun dipilih 25 siswa dari 1 kelas sebagai sampel yang diberi perlakuan dan 25 siswa dari kelas lain sebagai kontrol dalam uji coba ke dua. Terakhir dari SDN 07 Pagi Rawamangun dipilih 25 siswa dari 1 kelas sebagai sampel yang diberi perlakuan dan 25 siswa lain sebagai kontrol dalam uji coba ke tiga.

Pada masing-masing kelompok ada yang diberikan perlakuan dan ada yang tidak diberi perlakuan (sebagai kontrol), diikuti dengan pengambilan skor (postes) dengan menggunakan instrumen Perilaku Berwawasan Lingkungan. Kemudian dilakukan analisa dan paket materi pembelajaran inkuiri dievaluasi kembali, untuk selanjutnya dicobakan lagi ke kelompok yang berbeda. Demikian seterusnya sehingga didapat tiga kali uji coba.
Untuk pengumpulan data masing-masing uji coba, selain dilakukan pengambilan skor melalui kuesioner juga dilakukan observasi, pengumpulan angket dari para siswa serta wawancara dengan para guru kelas.

Penelitian ini termasuk penelitian pengembangan (Research and Development) yang mengacu pada rumusan Borg and Gall. Menurut Borg \& Gall ( 1983: 772), paket materi penelitian pengembangan ialah suatu proses yang digunakan untuk mengembangkan dan memvalidasi paket materi-paket materi pendidikan, seperti materi pembelajaran, buku teks, metode pembelajaran, dan lain-lain yang dilakukan dalam suatu rangkaian penelitian dan pengembangan.

Pelaksanaan penelitian ini menggunakan tiga metode penelitian, yaitu survei, evaluasi dan eksperimen. Survei digunakan sebagai studi pendahuluan untuk perencanaan dan pengembangan draft paket materi pembelajaran. Pengumpulan data dengan metode survei ini dilakukan melalui studi pustaka, wawancara dan kuesioner. Evaluasi dilakukan untuk mengetahui kelayakan draft paket materi pembelajaran yang dikembangkan berdasarkan hasil survei lapangan. Evaluasi dilakukan melalui validasi paket materi pembelajaran sebelum diujicobakan. Validasi yang dilakukan mencakup isi, sistematika, dan relevansinya yang berhubungan dengan tujuan pembelajaran. Eksperimen dilakukan melalui suatu proses pembelajaran di sekolah untuk mengetahui efektivitas pengembangan paket materi pembelajaran inkuiri.

Langkah-langkah penelitian terdiri dari tiga tahap yaitu : (1) tahap Penyusunan paket materi, (2) tahap Validasi paket materi dan Uji efektivitas terbatas, dan (3) tahap Rekomendasi paket materi, yang dilakukan terhadap paket materi akhir.

Adapun kegiatan-kegiatan yang dilakukan adalah sebagai berikut :

\section{Tahap Penyusunan Paket Materi}

Pada tahap ini, kegiatan penelitian meliputi : (1) Studi Pustaka, (2) Survei Lapangan, (3) Penyusunan Kisi-kisi Instrumen pengumpulan data, (4) Penyusunan Instrumen taksiran kebutuhan (Need Assessment), (5) Pengumpulan data lapangan, (6) Penyusunan rancangan Paket materi pembelajaran inkuiri, (7) Penyusunan Instrumen Perilaku Berwawasan Lingkungan, (8) Uji coba Validitas dan Reliabilitas Instrumen Perilaku Berwawasan Lingkungan.

\section{Tahap Validasi dan Uji Efektivitas Terbatas Paket Materi}

Tahap ini merupakan tahap pemantapan paket materi yang dikembangkan sebelum dilakukan

\begin{tabular}{|l|l|l|l|}
\hline Volume XI & Nomor 02 & Maret 2010 & ISSN 1411-1829 \\
\hline
\end{tabular}


eksperimen untuk menguji keefektifan paket materi pembelajaran inkuiri yang dikembangkan. Kegiatan yang dilakukan pada tahap ini menggunakan small treatment experiment (terdapat rangkaian kegiatan).

Pada tahap ini dilakukan tiga kali uji coba terbatas untuk mencapai bentuk paket materi yang valid. Pada setiap uji coba terdapat urutan perencanaan pelaksanaan - observasi - refleksi/evaluasi. Pada evaluasi diberikan tes untuk mengukur keefektifan paket materi melalui penguasaan materi yang diajarkan, setelah itu baru diberikan kuesioner untuk mengukur kecenderungan perilaku berwawasan lingkungan.

Implementasi paket materi pada uji coba pertama dilakukan di SDN 01 Pagi Rawamangun pada tanggal 2 - 16 September 2004, uji coba ke dua di SDN 05 Pagi Rawamangun pada tanggal 18 September - 3 Oktober 2004, dan uji coba ke tiga di SDN 07 Pagi Rawamangun pada tanggal 5 - 19 Oktober 2004.

Eksperimen untuk mengukur tingkat pencapaian pembelajaran melalui paket materi inkuiri dilakukan dengan desain eksperimen Randomized control-group posttest (Issac, 1984: 101), yakni melaksanakan kegiatan belajar-mengajar pada masing-masing kelompok peserta didik dengan diberi perlakuan, kemudian diikuti pemberian tes untuk mengukur penguasaan materi yang diajarkan. Setelah itu dilakukan pengambilan skor dengan menggunakan instrumen Perilaku berwawasan lingkungan pada kelompok perlakuan dan kelompok kontrol. Desain eksperimen yang dilakukan seperti di bawah ini :

\begin{tabular}{|c|c|c|}
\hline Kelompok & $\begin{array}{c}\text { Perlakua } \\
\text { n }\end{array}$ & Postes \\
\hline Eksperimen & $\mathrm{X}$ & $\mathrm{O}_{1}$ \\
\hline Kontrol & $\mathrm{C}$ & $\mathrm{O}_{2}$ \\
\hline
\end{tabular}

Gambar 2 : Desain eksperimen Randomized ControlKeterangan : Group Postest

X : Perlakuan dengan Paket Materi

Pembelajaran Inkuiri

C : Tanpa Perlakuan

$\mathrm{O}_{1}$ : tes pada kelompok eksperimen

$\mathrm{O}_{2}$ : tes pada kelompok tanpa perlakuan

\section{Tahap Rekomendasi Paket Materi}

Tahap ini merupakan langkah terakhir dari proses pengembangan paket materi dengan tujuan mendapatkan rekomendasi tentang paket materi pembelajaran inkuiri tersebut.

Dalam penelitian ini terdapat dua instrumen yang dikumpulkan datanya, yaitu (1) taksiran kebutuhan
(Need Assessment) dari guru-guru kelas V SD, orangtua siswa dan siswa serta (2) data perilaku siswa yang berwawasan lingkungan yang diperoleh melalui kuesioner.

Analisis data uji efektivitas materi pembelajaran inkuiri dilakukan secara kuantitatif. Analisis kuantitatif digunakan untuk menganalisis capaian skor variabel perilaku berwawasan lingkungan.

Melalui analisis terhadap skor postes variabel perilaku berwawasan lingkungan dapat diperoleh informasi efektif tidaknya suatu paket materi inkuiri yang digunakan. Analisis dilakukan secara statistik untuk setiap perlakuan dengan menggunakan uji $\mathrm{t}$ berpasangan.

Sebelum dilakukan analisis, data dari setiap uji coba dilakukan dengan penyajian data. Selanjutnya dilakukan pengujian normalitas dan homogenitas. Untuk uji normalitas digunakan uji Liliefors dan uji homogenitas digunakan uji Bartlett. Kemudian dilakukan analisis secara statistik terhadap capaian skor perilaku siswa dengan uji t berpasangan pada taraf signifikansi $\alpha=0,05$. Uji $\mathrm{t}$ berpasangan digunakan untuk mengetahui ada tidaknya perbedaan skor rata-rata perilaku antar kelompok secara keseluruhan. Hasil analisis skor ini merupakan indikator sesuai dan tidaknya penggunaan paket materi Pendidikan Lingkungan Hidup bagi siswa SD.

\section{HASIL PENELITIAN DAN PEMBAHASAN}

\section{Survei Kebutuhan Pembelajaran Pendidikan Lingkungan}

Hasil survei kebutuhan pembelajaran dilakukan dengan menggunakan kuesioner yang ditujukan kepada 10 siswa, 10 guru dan 10 orang tua siswa kelas V SD. Hasil survei dapat dikategorikan menjadi tiga, yaitu : (a) sangat membutuhkan dengan nilai 3, (b) membutuhkan dengan nilai 2, dan (c) tidak membutuhkan dengan nilai 1.

Adapun hasil skor deskripsi tingkat kebutuhan aspek Pendidikan Lingkungan Hidup peserta didik kelas V SD, adalah sebagai berikut:

\section{Tabel 2. Skor Deskripsi Tingkat Kebutuhan Aspek Pendidikan Lingkungan Hidup}

\begin{tabular}{|c|l|l|l|c|}
\hline $\begin{array}{c}\text { Aspe } \\
\mathbf{k}\end{array}$ & $\begin{array}{l}\text { Sangat } \\
\text { Dibutuh } \\
\text { kan }\end{array}$ & $\begin{array}{l}\text { Dibutuh } \\
\text { kan }\end{array}$ & $\begin{array}{l}\text { Tidak } \\
\text { Dibutuh } \\
\text { kan }\end{array}$ & $\begin{array}{c}\text { Juml } \\
\text { ah }\end{array}$ \\
\hline Udara & $\begin{array}{l}13 \text { orang } \\
=43,33 \%\end{array}$ & $\begin{array}{l}13 \text { orang } \\
=43,33 \%\end{array}$ & $\begin{array}{l}4 \text { orang }= \\
13,33 \%\end{array}$ & $\begin{array}{c}30 \\
\text { orang }\end{array}$ \\
\hline $\begin{array}{l}\text { Energ } \\
\text { i }\end{array}$ & $\begin{array}{l}4 \text { orang } \\
13,33 \%\end{array}$ & $\begin{array}{l}16 \text { orang } \\
=53,33 \%\end{array}$ & $\begin{array}{l}10 \text { orang } \\
=33,33 \%\end{array}$ & $\begin{array}{c}30 \\
\text { orang }\end{array}$ \\
\hline Air & 10 orang & 13 orang & 7 orang & 30 \\
\hline
\end{tabular}

\begin{tabular}{|l|l|l|l|}
\hline Volume XI & Nomor 02 & Maret 2010 & ISSN 1411-1829 \\
\hline
\end{tabular}




\begin{tabular}{|l|c|c|l|c|}
\hline & $=33,33 \%$ & $=43,33 \%$ & $\begin{array}{l}= \\
23,33 \%\end{array}$ & orang \\
\hline $\begin{array}{l}\text { Samp } \\
\text { ah }\end{array}$ & $\begin{array}{l}14 \text { orang } \\
=46,67 \%\end{array}$ & $\begin{array}{l}13 \text { orang } \\
=43,33 \%\end{array}$ & $\begin{array}{l}3 \text { orang } \\
=\end{array}$ & $\begin{array}{c}30 \\
\text { orang }\end{array}$ \\
\hline
\end{tabular}

Sesuai dengan Tabel 2, skor deskripsi materi Pendidikan Lingkungan Hidup yang terdiri dari aspek materi udara, energi, air dan sampah; untuk kategori sangat dibutuhkan oleh siswa kelas V SD masingmasing sebesar 43,33\%; 13,33\%; 33,33\%; 46,67\%; untuk kategori dibutuhkan sebesar 43,33\%; 53,33\%; 43,33\%; 43,33\%; untuk kategori tidak dibutuhkan sebesar 13,33\%; 33,33\%; 23,33\%; 10,00\%. Secara lebih rinci dapat dikatakan bahwa dari survei ditemukan bahwa para siswa kelas V SD membutuhkan pembelajaran Pendidikan Lingkungan Hidup berturut-turut tentang sampah sebesar 90,00\%, tentang udara sebesar $86,67 \%$, tentang air sebesar $76,67 \%$, dan tentang energi sebesar. 66,67\%.

Dari gambaran di atas, terlihat bahwa taksiran kebutuhan pembelajaran Pendidikan Lingkungan Hidup tentang sampah merupakan materi yang paling dibutuhkan oleh siswa, diikuti udara, air dan energi.

\section{Paket materi Pembelajaran Inkuiri}

Pembelajaran inkuiri merupakan suatu prosedur pembelajaran yang sistematis untuk peningkatan kapasitas peserta didik dengan memanfaatkan sumbersumber belajar di lingkungan siswa, yang mempersiapkan anak melakukan eksperimen sendiri dan mengaitkan materi pelajaran dengan fenomena kehidupan sehari-hari. Mekanisme pembelajaran tersebut meliputi perencanaan, implementasi kegiatan belajar dan evaluasi.

Berdasarkan hasil penelitian yang dilakukan sesuai dengan kebutuhan belajar siswa yang dikaitkan dengan perilaku berwawasan lingkungan maka materi-materi pembelajaran Pendidikan Lingkungan Hidup yang dibutuhkan sebagaimana disajikan pada tabel 3 sebagai berikut :

\section{Tabel 3 : Aspek Pembelajaran Pendidikan Lingkungan Hidup}

\begin{tabular}{|l|l|}
\hline $\begin{array}{l}\text { Pokok } \\
\text { Bahasan }\end{array}$ & Sub Pokok Bahasan \\
\hline Udara & $\begin{array}{l}\text {-Pencemaran Udara } \\
\text {-Akibat Pencemaran Udara }\end{array}$ \\
\hline Air & $\begin{array}{l}\text {-Pencemaran Air } \\
\text {-Akibat Pencemaran Air } \\
\text {-Hemat Air }\end{array}$ \\
\hline Sampah & -Pengelompokan sampah \\
\hline
\end{tabular}

\begin{tabular}{|l|l|l|l|}
\hline Volume XI & Nomor 02 & Maret 2010 & ISSN 1411-1829 \\
\hline
\end{tabular}

\begin{tabular}{|l|l|}
\hline & -Daur ulang sampah \\
\hline Energi & $\begin{array}{l}\text {-Jenis-jenis Energi } \\
\text {-Hemat Energi }\end{array}$ \\
\hline
\end{tabular}

\section{Hasil Validasi Pengembangan Paket Materi Pembelajaran Inkuiri}

Validasi dilakukan terhadap paket materi pembelajaran inkuiri melalui (1) penilaian yang dilakukan oleh para guru pengajar Pendidikan Lingkungan Hidup; serta (2) uji terhadap capaian skor.

\section{Deskripsi Hasil Uji Coba Efektivitas Paket materi Pembelajaran Inkuiri}

Uji coba dalam kegiatan pembelajaran dilakukan sebanyak tiga kali. Selanjutnya, skor perilaku berwawasan lingkungan yang diperoleh dalam penelitian ini merupakan salah satu indikator bagi efektif-tidaknya paket materi pembelajaran inkuiri yang digunakan dalam Pendidikan Lingkungan Hidup.

Deskripsi data dimaksudkan untuk memberikan gambaran tentang ukuran pemusatan, dan ukuran persebaran data yang dikumpulkan. Ukuran pemusatan data yang ditampilkan adalah rerata (mean), nilai tengah (median), dan varian terbanyak yang muncul (modus) serta distribusi frekuensi.

Bentuk berikut ini berturut-turut gambaran deskriptif mengenai skor perilaku berwawasan lingkungan siswa SD dengan tiga kali uji coba, baik yang mengalami perlakuan maupun kontrol. Skor siswa yang mengalami perlakuan dibandingkan dengan skor siswa yang tidak mengalami perlakuan (kelompok kontrol) pada tiap-tiap uji coba.

Data tentang perilaku siswa yang berwawasan lingkungan didapat dengan menggunakan kuesioner. Pemberian skor terhadap jawaban siswa menggunakan skala antara 1 sampai 3, sehingga dari 26 butir pernyataan dalam kuesioner perilaku siswa yang berwawasan lingkungan akan diperoleh rentang skor teoritik antara 29 sampai dengan 78.

\section{Skor Perilaku Berwawasan Lingkungan pada Uji coba ke-1 \\ Berdasarkan data penelitian diperoleh rentangan skor antara 47 sampai dengan 62, dengan harga rata- rata $($ mean $)=56,48$ dan simpangan baku $(S D)=4,11$ ; median $=57$ dan modus $=57$. Selanjutnya distribusi frekuensi skor perilaku berwawasan lingkungan pada kelompok perlakuan dapat dilihat pada tabel 4 .}


Tabel 4. Distribusi Frekuensi Skor Perilaku Berwawasan Lingkungan Kelompok Perlakuan (Uji coba ke-1)

\begin{tabular}{|c|c|c|c|}
\hline Nomor & $\begin{array}{c}\text { Interval } \\
\text { Kelas }\end{array}$ & $\begin{array}{c}\text { Frekuensi } \\
\text { Absolut }\end{array}$ & $\begin{array}{c}\text { Frekuensi } \\
\text { Relatif (\%) }\end{array}$ \\
\hline 1 & $47-49$ & 2 & 8,00 \\
\hline 2 & $50-52$ & 3 & 12,00 \\
\hline 3 & $53-55$ & 2 & 8,00 \\
\hline 4 & $56-58$ & 9 & 36,00 \\
\hline 5 & $59-61$ & 8 & 32,00 \\
\hline 6 & $62-64$ & 1 & 4,00 \\
\hline & Jumlah & 25 & 100,00 \\
\hline
\end{tabular}

Berdasarkan data penelitian diperoleh rentangan skor antara 44 sampai dengan 56, dengan harga rata-rata $($ mean $)=50,32$ dan simpangan baku $(S D)=3,52$; median $=50$ dan modus $=53$. Selanjutnya distribusi frekuensi skor perilaku berwawasan lingkungan pada kelompok kontrol dapat dilihat pada tabel 5.

Tabel 5. Distribusi Frekuensi Skor Perilaku Berwawasan Lingkungan Kelompok Kontrol.

\begin{tabular}{|c|c|c|c|}
\hline Nomor & $\begin{array}{c}\text { Interval } \\
\text { Kelas }\end{array}$ & $\begin{array}{c}\text { Frekuensi } \\
\text { Absolut }\end{array}$ & $\begin{array}{c}\text { Frekuensi } \\
\text { Relatif (\%) }\end{array}$ \\
\hline 1 & $44-45$ & 4 & 16,00 \\
\hline 2 & $46-47$ & 3 & 12,00 \\
\hline 3 & $48-49$ & 1 & 4,00 \\
\hline 4 & $50-51$ & 5 & 20,00 \\
\hline 5 & $52-53$ & 9 & 36,00 \\
\hline 6 & $54-56$ & 3 & 12,00 \\
\hline & Jumlah & 25 & 100,00 \\
\hline
\end{tabular}

Skor Perilaku Berwawasan Lingkungan pada Uji coba ke-2

Berdasarkan data penelitian kelompok perlakuan diperoleh rentangan skor antara 56 sampai dengan 71, dengan harga rata-rata (mean) $=63,04$ dan simpangan baku $(S D)=4,41$; median $=63$ dan modus $=63$. Selanjutnya distribusi frekuensi skor perilaku berwawasan lingkungan pada kelompok perlakuan dapat dilihat pada tabel 6 .

Tabel 6.Distribusi Frekuensi Skor Perilaku Berwawasan Lingkungan Kelompok Perlakuan (Uji coba ke-2)

\begin{tabular}{|c|c|c|c|}
\hline Nomor & $\begin{array}{c}\text { Interval } \\
\text { Kelas }\end{array}$ & $\begin{array}{c}\text { Frekuensi } \\
\text { Absolut }\end{array}$ & $\begin{array}{c}\text { Frekuensi } \\
\text { Relatif (\%) }\end{array}$ \\
\hline 1 & $56-58$ & 4 & 16,00 \\
\hline 2 & $59-61$ & 6 & 24,00 \\
\hline
\end{tabular}

\begin{tabular}{|l|l|}
\hline Volume XI & Nomor 02 \\
\hline
\end{tabular}

\begin{tabular}{|c|c|c|c|}
\hline 3 & $62-64$ & 6 & 24,00 \\
\hline 4 & $65-67$ & 4 & 16,00 \\
\hline 5 & $68-70$ & 4 & 16,00 \\
\hline 6 & $71-73$ & 1 & 4,00 \\
\hline & Jumlah & 25 & 100,00 \\
\hline
\end{tabular}

Berdasarkan data penelitian kelompok kontrol diperoleh rentangan skor antara 45 sampai dengan 60 , dengan harga rata-rata (mean) $=50,44$ dan simpangan baku $(S D)=3,81 ;$ median $=51$ dan modus $=51$. Selanjutnya distribusi frekuensi skor perilaku berwawasan lingkungan pada kelompok kontrol dapat dilihat pada tabel 7 .

Tabel 7. Distribusi Frekuensi Skor Perilaku Berwawasan Lingkungan Kelompok Kontrol.

\begin{tabular}{|c|c|c|c|}
\hline Nomor & $\begin{array}{c}\text { Interval } \\
\text { Kelas }\end{array}$ & $\begin{array}{c}\text { Frekuensi } \\
\text { Absolut }\end{array}$ & $\begin{array}{c}\text { Frekuensi } \\
\text { Relatif (\%) }\end{array}$ \\
\hline 1 & $45-47$ & 6 & 24,00 \\
\hline 2 & $48-50$ & 6 & 24,00 \\
\hline 3 & $51-53$ & 10 & 40,00 \\
\hline 4 & $54-56$ & 1 & 4,00 \\
\hline 5 & $57-59$ & 1 & 4,00 \\
\hline 6 & $60-62$ & 1 & 4,00 \\
\hline & Jumlah & 25 & 100,00 \\
\hline
\end{tabular}

Skor Perilaku Berwawasan Lingkungan pada Uji coba ke-3

Berdasarkan data penelitian kelompok perlakuan diperoleh rentangan skor antara 65 sampai dengan 75, dengan harga rata-rata (mean) $=71,84$ dan simpangan baku $(S D)=2,27 ;$ median $=72$ dan modus $=73$. Selanjutnya distribusi frekuensi skor perilaku berwawasan lingkungan pada kelompok perlakuan dapat dilihat pada tabel 8.

Tabel 8.Distribusi Frekuensi Skor Perilaku Berwawasan Lingkungan Kelompok Perlakuan (Uji coba ke-3)

\begin{tabular}{|c|c|c|c|}
\hline Nomor & $\begin{array}{c}\text { Interval } \\
\text { Kelas }\end{array}$ & $\begin{array}{c}\text { Frekuensi } \\
\text { Absolut }\end{array}$ & $\begin{array}{c}\text { Frekuensi } \\
\text { Relatif (\%) }\end{array}$ \\
\hline 1 & $65-66$ & 1 & 4,00 \\
\hline 2 & $67-68$ & 0 & 0,00 \\
\hline 3 & $69-70$ & 4 & 16,00 \\
\hline 4 & $71-72$ & 8 & 32,00 \\
\hline 5 & $73-74$ & 11 & 44,00 \\
\hline 6 & $75-76$ & 1 & 4,00 \\
\hline & Jumlah & 25 & 100,00 \\
\hline
\end{tabular}

Maret 2010

ISSN 1411-1829 
Berdasarkan data penelitian kelompok kontrol diperoleh rentangan skor antara 45 sampai dengan 60, dengan harga rata-rata (mean) $=50,40$ dan simpangan baku $(S D)=4,89 ;$ median $=48$ dan modus $=51$. Distribusi frekuensi skor perilaku berwawasan lingkungan pada kelompok kontrol dapat dilihat pada tabel 9.

Tabel 9. Distribusi Frekuensi Skor Perilaku Berwawasan Lingkungan Kelompok Kontrol

\begin{tabular}{|c|c|c|c|}
\hline Nomor & $\begin{array}{c}\text { Interval } \\
\text { Kelas }\end{array}$ & $\begin{array}{c}\text { Frekuensi } \\
\text { Absolut }\end{array}$ & $\begin{array}{c}\text { Frekuensi } \\
\text { Relatif (\%) }\end{array}$ \\
\hline 1 & $44-47$ & 10 & 40,00 \\
\hline 2 & $48-50$ & 6 & 24,00 \\
\hline 3 & $51-53$ & 7 & 28,00 \\
\hline 4 & $54-56$ & 1 & 4,00 \\
\hline 5 & $57-59$ & 0 & 0,00 \\
\hline 6 & $60-62$ & 1 & 4,00 \\
\hline & Jumlah & 25 & 100,00 \\
\hline
\end{tabular}

Adapun hasil perhitungan uji normalitas, uji homogenitas dan uji-t untuk Uji coba ke-1 dapat dilihat pada tabel 10 .

Tabel 10 Hasil uji coba ke-1

\begin{tabular}{|c|c|c|c|c|c|c|}
\hline \multirow[t]{2}{*}{$\begin{array}{l}\text { Samp } \\
\text { el }\end{array}$} & \multicolumn{2}{|c|}{$\begin{array}{c}\text { Uji } \\
\text { Normalitas }\end{array}$} & \multicolumn{2}{|c|}{$\begin{array}{c}\text { Uji } \\
\text { Homogenita } \\
\text { s } \\
\end{array}$} & \multicolumn{2}{|c|}{ Uji - t } \\
\hline & $\mathrm{L}_{0}$ & $\begin{array}{c}\mathrm{L}_{\mathrm{t}} \\
\alpha= \\
0.05\end{array}$ & $\begin{array}{c}\mathrm{X} \\
\text { hitun } \\
\mathrm{g}\end{array}$ & $\begin{array}{c}\mathrm{X} \\
\text { tabe } \\
1 \\
\alpha= \\
0.05\end{array}$ & $\begin{array}{c}\text { t } \\
\text { hitu } \\
\text { ng }\end{array}$ & $\begin{array}{c}\mathrm{t} \\
\text { tabe } \\
1 \\
\alpha= \\
0.05\end{array}$ \\
\hline $\begin{array}{l}\text { Perla } \\
\text { kuan }\end{array}$ & 0.13 & 0.17 & 10.96 & $\begin{array}{c}11.1 \\
0\end{array}$ & \multirow[t]{2}{*}{5.69} & \multirow[t]{2}{*}{2.06} \\
\hline $\begin{array}{l}\text { Kontr } \\
\text { ol }\end{array}$ & 0.12 & 0.17 & 10.96 & $\begin{array}{c}11.1 \\
0\end{array}$ & & \\
\hline & \multicolumn{2}{|c|}{ Normal } & \multicolumn{2}{|c|}{ Homogen } & \multicolumn{2}{|c|}{$\begin{array}{c}\text { Berbeda } \\
\text { nyata }\end{array}$} \\
\hline
\end{tabular}

Berdasarkan hasil perhitungan uji normalitas dan uji homogenitas pada tabel 10 ditemukan bahwa skor perilaku berwawasan lingkungan baik yang berasal dari kelompok perlakuan dan kelompok kontrol memberikan hasil data yang berdistribusi normal dan homogen. Hal ini menunjukkan bahwa data skor perilaku tersebut dapat dilakukan pengujian hipotesisnya.

Adapun hipotesis yang diajukan untuk keperluan uji-t ini adalah Ho = Tidak terdapat perbedaan yang signifikan antara kelompok perlakuan dengan kelompok kontrol, sedangkan $\mathrm{Hi}=$ Terdapat perbedaan yang signifikan antara kelompok perlakuan dengan kelompok kontrol. Berdasarkan hasil pengujian uji-t menunjukkan bahwa t hitung $=5,69$ sedangkan $\mathrm{t}$ tabel $=2,06$. Oleh karena $\mathrm{t}$ hitung $>\mathrm{t}$ tabel, maka Ho ditolak. Hal ini berarti ada perbedaan yang signifikan antara kelompok perlakuan dengan kelompok kontrol.

Adapun hasil perhitungan uji normalitas, uji homogenitas dan uji-t untuk Uji coba ke-2 dapat dilihat pada tabel 11.

\section{Tabel 11 Hasil uji coba ke-2}

\begin{tabular}{|c|c|c|c|c|c|c|}
\hline \multirow[t]{2}{*}{$\begin{array}{l}\text { Samp } \\
\text { el }\end{array}$} & \multicolumn{2}{|c|}{$\begin{array}{c}\text { Uji } \\
\text { Normalitas }\end{array}$} & \multicolumn{2}{|c|}{$\begin{array}{c}\text { Uji } \\
\text { Homogenit } \\
\text { as } \\
\end{array}$} & \multicolumn{2}{|c|}{ Uji - t } \\
\hline & $\mathrm{L}_{0}$ & $\begin{array}{c}\mathrm{L}_{\mathrm{t}} \\
\alpha= \\
0.05\end{array}$ & $\begin{array}{c}\mathrm{X} \\
\text { hitun } \\
\mathrm{g}\end{array}$ & $\begin{array}{c}\mathrm{X} \\
\text { tabe } \\
1 \\
\alpha= \\
0.05\end{array}$ & $\begin{array}{c}\mathrm{t} \\
\text { hitu } \\
\mathrm{ng}\end{array}$ & $\begin{array}{c}\mathrm{t} \\
\text { tabel } \\
\alpha= \\
0.05\end{array}$ \\
\hline $\begin{array}{l}\text { Perla } \\
\text { kuan }\end{array}$ & $\begin{array}{l}0 . \\
14\end{array}$ & 0.17 & 10.96 & $\begin{array}{c}11.1 \\
0\end{array}$ & \multirow[t]{2}{*}{$\begin{array}{c}10.8 \\
1\end{array}$} & \multirow[t]{2}{*}{2.06} \\
\hline $\begin{array}{l}\text { Kontr } \\
\text { ol }\end{array}$ & $\begin{array}{l}0 . \\
13\end{array}$ & 0.17 & 10.96 & $\begin{array}{c}11.1 \\
0 \\
\end{array}$ & & \\
\hline & \multicolumn{2}{|c|}{ Normal } & \multicolumn{2}{|c|}{ Homogen } & \multicolumn{2}{|c|}{$\begin{array}{c}\text { Berbeda } \\
\text { nyata }\end{array}$} \\
\hline
\end{tabular}

Berdasarkan hasil perhitungan uji normalitas dan uji homogenitas pada tabel 11 ditemukan bahwa skor perilaku berwawasan lingkungan baik yang berasal dari kelompok perlakuan dan kelompok kontrol memberikan hasil data yang berdistribusi normal dan homogen. Hal ini menunjukkan bahwa data skor perilaku tersebut dapat dilakukan pengujian hipotesisnya.

Berdasarkan hasil pengujian uji-t menunjukkan bahwa t hitung $=10,81$ sedangkan $\mathrm{t}$ tabel $=2,06$. Oleh karena t hitung $>\mathrm{t}$ tabel, maka Ho ditolak. Hal ini berarti ada perbedaan yang signifikan antara kelompok perlakuan dengan kelompok kontrol.

Adapun hasil perhitungan uji normalitas, uji homogenitas dan uji-t untuk Uji coba ke-3 dapat dilihat pada tabel 12 .

Tabel 12 Hasil uji coba ke-3

\begin{tabular}{|l|c|c|c|c|c|c|}
\hline $\begin{array}{l}\text { Samp } \\
\text { el }\end{array}$ & \multicolumn{2}{|c|}{$\begin{array}{c}\text { Uji } \\
\text { Normalitas }\end{array}$} & \multicolumn{2}{c|}{$\begin{array}{c}\text { Uji } \\
\text { Homogenita } \\
\text { sog }\end{array}$} & \multicolumn{2}{c|}{ Uji - t } \\
\hline & $\mathrm{L}_{0}$ & $\begin{array}{c}\mathrm{L}_{\mathrm{t}} \\
\alpha=\end{array}$ & $\begin{array}{c}\mathrm{X} \\
\text { hitu }\end{array}$ & $\begin{array}{c}\mathrm{X} \\
\text { tabel }\end{array}$ & $\begin{array}{c}\mathrm{t} \\
\text { hitu }\end{array}$ & $\begin{array}{c}\mathrm{t} \\
\text { tabe }\end{array}$ \\
\hline
\end{tabular}

\section{\begin{tabular}{|l|l|l|l|}
\hline Volume XI & Nomor 02 & Maret 2010 & ISSN 1411-1829 \\
\hline
\end{tabular}}




\begin{tabular}{|c|c|c|c|c|c|c|}
\hline & & 0.05 & ng & $\begin{array}{c}\alpha= \\
0.05\end{array}$ & ng & $\begin{array}{c}\mathrm{l} \\
\alpha= \\
0.05\end{array}$ \\
\hline $\begin{array}{l}\text { Perla } \\
\text { kuan }\end{array}$ & 0.13 & 0.17 & $\begin{array}{c}10.9 \\
6\end{array}$ & 11.10 & \multirow[t]{2}{*}{$\begin{array}{c}19.8 \\
9\end{array}$} & \multirow[t]{2}{*}{2.06} \\
\hline $\begin{array}{l}\text { Kontr } \\
\text { ol }\end{array}$ & 0.15 & 0.17 & $\begin{array}{c}10.9 \\
6\end{array}$ & 11.10 & & \\
\hline & \multicolumn{2}{|c|}{ Normal } & \multicolumn{2}{|c|}{ Homogen } & \multicolumn{2}{|c|}{$\begin{array}{c}\text { Berbeda } \\
\text { nyata }\end{array}$} \\
\hline
\end{tabular}

Berdasarkan hasil perhitungan uji normalitas dan uji homogenitas pada tabel 12 ditemukan bahwa skor perilaku berwawasan lingkungan baik yang berasal dari kelompok perlakuan dan kelompok kontrol memberikan hasil data yang berdistribusi normal dan homogen. Hal ini menunjukkan bahwa data skor perilaku tersebut dapat dilakukan pengujian hipotesisnya.

Berdasarkan hasil pengujian uji-t menunjukkan bahwa $\mathrm{t}$ hitung $=19,89$ sedangkan $\mathrm{t}$ tabel $=2,06$. Oleh karena t hitung $>\mathrm{t}$ tabel, maka Ho ditolak. Hal ini berarti ada perbedaan yang signifikan antara kelompok perlakuan dengan kelompok kontrol.

Hal ini berarti bahwa paket materi pembelajaran inkuiri lebih efektif dibandingkan pembelajaran konvensional, dalam upaya meningkatkan perilaku berwawasan lingkungan siswa SD.

Adapun keluaran dari paket materi pembelajaran inkuiri dapat disajikan pada gambar berikut :

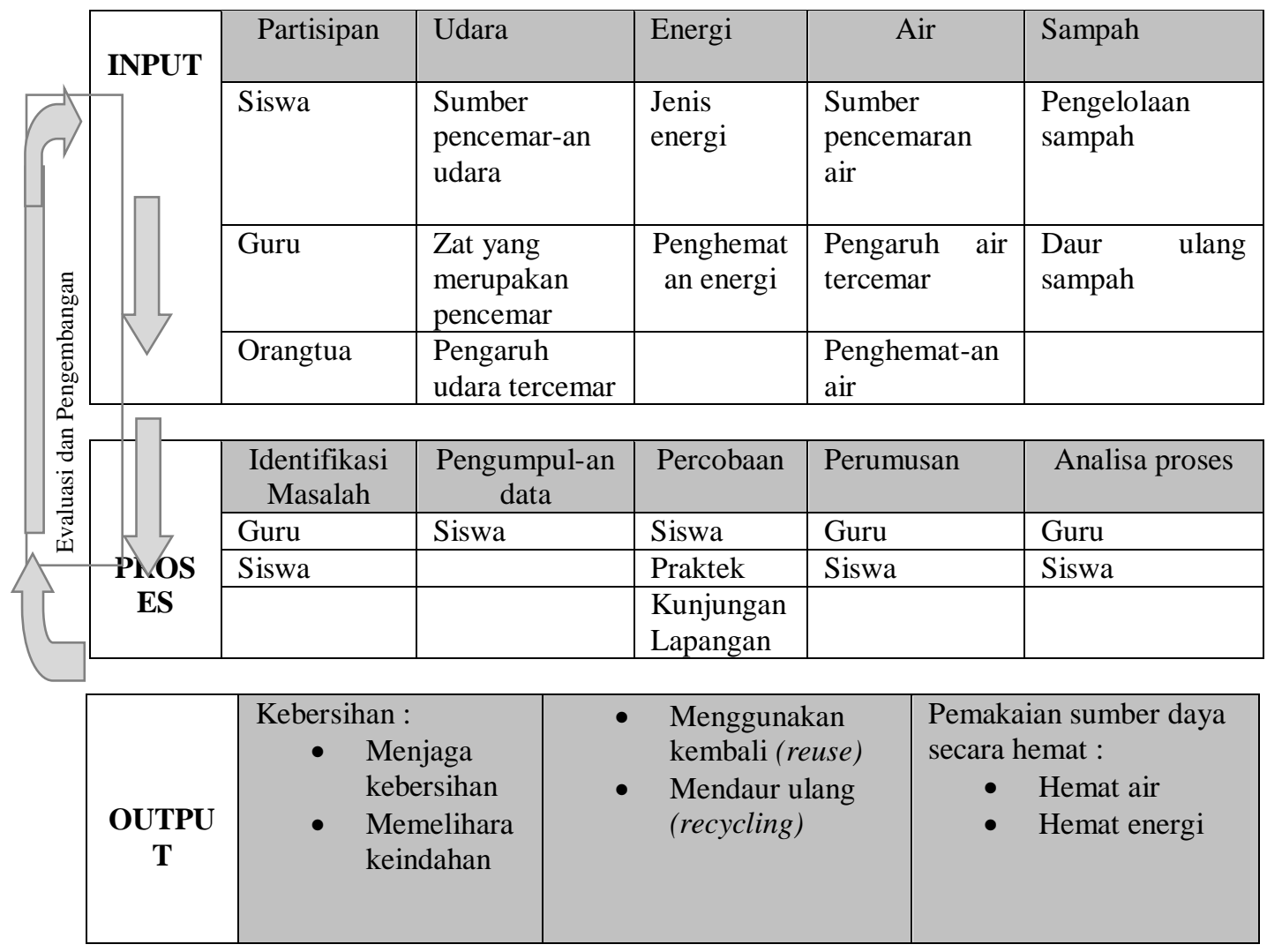

Gambar 3 : Bagan alur paket materi inkuiri yang direkomendasikan

\section{KESIMPULAN}

Dari hasil penelitian terhadap paket materi pembelajaran inkuiri yang dilakukan pada siswa Sekolah Dasar di Jakarta Timur, dapat disimpulkan bahwa: (1) Paket materi inkuiri yang disusun dengan memanfaatkan sumber-sumber belajar yang ada di lingkungan siswa dapat meningkatkan perilaku berwawasan lingkungan siswa. Hal ini ditunjukkan oleh hasil uji coba yang dilakukan, yakni adanya perbedaan skor perilaku antara kontrol dan sesudah perlakuan. Sehingga dalam hal ini skor perilaku berwawasan lingkungan lebih tinggi setelah diberi pembelajaran dengan metode inkuiri. (2) Paket materi inkuiri yang dibutuhkan dalam rangka peningkatan perilaku berwawasan lingkungan lebih

\begin{tabular}{|l|l|l|l|}
\hline Volume XI & Nomor 02 & Maret 2010 & ISSN 1411-1829 \\
\hline
\end{tabular}


tepat diangkat dari realitas masalah lingkungan yang terjadi. Dengan demikian, paket materi pembelajaran inkuiri berbasis kebutuhan cukup efektif digunakan dalam pembelajaran inkuiri. (3) Efektivitas pengembangan pembelajaran inkuiri teruji sehingga diharapkan terjadi peningkatan perilaku berwawasan lingkungan pada siswa SD.

\section{SARAN}

Berdasarkan sejumlah pengalaman yang didapatkan dari keseluruhan proses penelitian, maka berikut ini beberapa saran dapat diajukan: (1) Para guru yang menjadi fasilitator dalam pembelajaran Pendidikan Lingkungan Hidup, hendaknya senantiasa meningkatkan dan mengembangkan pengetahuan dan wawasannya sehingga pengajarannya menjadi lebih kreatif. Hal ini dapat mendorong siswa menjadi lebih tertarik dan memudahkan siswa mencapai tujuan pembelajarannya. Untuk itu perlu diprogramkan suatu pelatihan tersendiri bagi para guru. Program ini diharapkan dapat membantu siswa untuk memahami masalah lingkungan sehingga diharapkan terjadi perubahan perilaku ke arah yang lebih baik, (2) Penelitian dapat dilanjutkan dengan waktu yang lebih panjang dari 4 bulan, sehingga perubahan perilaku siswa dapat lebih diamati, (3) Peralatan dan materi percobaan dapat ditambah, sehingga membantu siswa dalam lebih memahami masalah lingkungan hidup. Selain itu bisa ditambahkan kunjungan lapangan ke pabrik, lingkungan pemukiman, hotel dan kompleks bangunan dan sebagainya, untuk melihat bagaimana tingkat pengatasan yang dilakukan dalam hal pencemaran air, pencemaran udara, dan penggunaan energi.

\section{REKOMENDASI}

Mengacu pada hasil penelitian, maka rekomendasi yang dapat diajukan berkenaan dengan penggunaan paket materi pembelajaran inkuiri dalam Pendidikan Lingkungan Hidup adalah sebagai berikut: (1) Karena telah dibuktikan signifikansi penggunaannya, upaya menyebarluaskan paket materi pembelajaran inkuiri dalam Pendidikan Lingkungan Hidup dapat dilaksanakan ke seluas mungkin satuan-satuan pendidikan pengajaran setara. Sesuai dengan hakikatnya, pengembangan paket materi inkuiri akan lebih membantu siswa untuk lebih siap melakukan eksperimen sendiri dengan memanfaatkan sumber-sumber belajar yang ada di sekitar lingkungan siswa. Dengan demikian pengetahuannya semakin bertambah, dan lebih terarah untuk berperilaku berwawasan lingkungan, (2) Paket materi pembelajaran inkuiri dalam
Pendidikan Lingkungan Hidup ini dapat meningkatkan pola pendidikan yang lebih berfokus kepada siswa. Hal ini dapat memperbaiki metodemetode sebelumnya yang lebih berfokus kepada guru. Oleh karena itu metode ini direkomendasikan untuk secara khusus membantu guru dalam peningkatan kreatifitas dan kemampuannya dalam melakukan pendidikan, (3) Program pembinaan dan pelatihan kepada siswa, guru, dan pengelola lain harus dirancang dengan baik untuk meningkatkan pola pikir siswa, guru, dan pengelola lain untuk lebih siap mengantisipasi upaya-upaya penyelamatan lingkungan hidup seperti yang telah digalakkan oleh Badan-badan Dunia/Pemerintah seperti pengatasan global warming, go green, dan sebagainya, dan (4) Penerapan paket materi inkuiri pada pembelajaran Pendidikan Lingkungan Hidup membutuhkan pengkondisian seluruh pihak terkait, misalnya orangtua, masyarakat, dan Pemerintah terkait.

\section{DAFTAR PUSTAKA}

Bapedal, Pendidikan Lingkungan SD, Jakarta:2004

Baron, Robert \& Donn Byrne, Social Psychology: Understanding Human Interaction, Boston: Allyn\&Bacon, 1991

Barrow, C. J., Developing the Environment, Problems \& Management, London: Longman Scientific \& Technical, 1995

Berndt, Thomas, Child Development, Dubuque: Brown \& Benchmark, 1997

Beroya, Mary Antonette, A People's Guide Book to The Environment, Hongkong: Documentation for Action Groups in Asia, 2000

Borg, Walter dan Meredith Gall, Educational Research An Introduction. $4^{\text {th }}$ ed., New York: Longman. 1983.

BPS, SensusPendudukIndonesia,2009

http://www.datastatistikindonesia.com/componento

Bruner, J.S., The Relevance of Education, New York: Norton, 1971

Chiras, Daniel, Environmental Science: A Framework for Decision Making, San Yuan: The Benjamin Publishing, 1985

\section{\begin{tabular}{|l|l|l|l|}
\hline Volume XI & Nomor 02 & Maret 2010 & ISSN 1411-1829 \\
\hline
\end{tabular}}


Chiras, Daniel, Environment Science. Action for a Sustainable Future, Redwood City, California: The Benjamin/Cummings Publ. Co. Inc., 1991

Dewey, John, Democracy and Education, New York: Macmillan, Inc., 1961

Dick and Carey, The Systematic Designs of Instruction, New York: Harper Collins Publisher, 1996

Djaali, Psikologi Pendidikan, Jakarta: Program Pasca Sarjana Universitas Negeri Jakarta, 2000

Esler, William \& Mary Esler, Teaching Elementary Science, California: Wadsworth Publishing Company, 1996

Gagne, Robert, Essentials of Learning for Instructions, Hindale: The Dryen Press, 1975

Gagne, Robert and Leslie J. Briggs, Principles of Instructional Design, New York: Holt, Rinehart and Winston, 1979

Gifford, Robert, Environmental Psychology :Principles and Practice, Boston: Allyn, 1987

Ginn, Jean Piaget-Intellectual Development. 2004 http://www.sk.com.br/skpiaget.html

Hadi, Sudharto, Dimensi Lingkungan Perencanaan dan Pembangunan, Yogyakarta: Gadjah Mada University Press, 2001

Hamzah, Syukri, Model Pengembangan Bahan Ajar Pendidikan Lingkungan Hidup Berbasis Lokal dalam Mata Pelajaran Pengetahuan Sosial Kelas IV SD di Rejang Lebong, Disertasi, Jakarta: Universitas Negeri Jakarta, 2005

Hannigan, John, Environmental Sociology, $2^{\text {nd }}$ Edition, New York: Routledge, 2006

Heinich, Robert, Michael Molenda and James D. Russel, Introduction Media and The New Technology of Instruction, New York : Mc Millan Publishing Company, 1989

Isaac, Stephen and William B. Michael., Handbook in research and evaluation, $2^{\text {nd }} E d$., San Diego: Edits Publishers, 1984

Joyce, Bruce and Marsha Weil, Models of Teaching, $2^{\text {nd }}$ Edition, New Jersey: Prentiss Hall, 1980

Karli, Hilda, Pengembangan Model Pembelajaran Terpadu tentang Mahluk Hidup dan Benda- benda di Sekitar Kita untuk Meningkatkan Keterampilan Berpikir Rasional Siswa SD Kelas III, Tesis, Bandung: UPI, 2000

Krech, David, Richard S. Crutchfield dan Egerton L. Ballachey, Individual in Society, Singapore:McGraw-Hill, 1988

Kuslan, L \& Harris Stone, Teaching Children Science : An Inquiry Approach, California: Wadsworth Publishing Company, 1968

Lanyon, Richard and Leonard D. Goodstein, Personality Assessment, New York: John Wiley \& Sons, 1977

Martin, Garry and Joseph Pear, Behavior Modification : what is it and how to do it?, London: Prentice Hall International Inc., 1992

Meadows, Donella, Batas-Batas Pertumbuhan , Jakarta: Gramedia, 1980

Michael, J.P., and Abraham M.R., “An Inquiry Formal Laboratorium Program for General Chemistry”, Journal of Chemical Education Vol 56-2, 1979

Miller, G. Tyler, Living in the Environment An Introduction to Environmental Science Fourth Edition, California: Wardsworth Publishing Company,1986

Mulyasa, E. Kurikulum Berbasis Kompetensi. Konsep, Karakteristik, dan Implementasi, Dikdasmen, 2002.

Monks, F.J., and Knoers, A.M.P., Ontwikkelings Psychologie, terjemahan Psikologi Perkembangan, Jogjakarta: Gajah Mada University Press, 1999

Nirarita, Endah, Pendidikan Lingkungan untuk Siswa Sekolah Dasar Kelas 4 - 6 (Taman Nasional Gunung Halimun), Sukabumi: Biodiversity Conservation Project and Wetlands, 1999

Odum, Eugene, Fundamentals of Ecology, Philadelphia: WB Saunders Company, 1971

Palmer, Joy A., Environmental Education in the $21^{\text {st }}$ Century, Theory, Practice, Progress and Promise, USA: Taylor \& Francis e-Library, 2003

Poniah, Wimala, Environmental Education for Biodiversity and Sustainable Development, ed. Mohamad Sorjani dan Monoca Hale, Jakarta: University of Indonesia in

\begin{tabular}{|c|c|c|c|}
\hline Volume XI & Nomor 02 & Maret 2010 & ISSN 1411-1829 \\
\hline
\end{tabular}


cooperation with London Guildhall University, 1977

Putrawan, M., Pendidikan dalam Menanggulangi Pemanasan Global, Bahan Seminar dan Workshop Nasional, 11 Juni 2008, Jakarta: Universitas Negeri Jakarta, 2008

Robin, Stephen, Essentials of Organizational Behavior, California: Prentice Hall, 2000

Romiszowski, Developing Auto Instructional Materials, Philadelphia: Nicolas Publishing, 1986

Rotter, J, The Social Learning Theory,2001 http://psych.fullerton.e.u/jmeearns/rotter:ht $\underline{\mathrm{m}}$

Salim, Emil, Lingkungan Hidup dan Pembangunan, Jakarta: Mutiara Sumber Widya, 1993

Salim, Emil, Sustainable Development : An Indonesia Perspective, Paper presented at AISEC. Jakarta: 9-10 March 1989

Sarwono, Sarlito Wirawan, Psikologi Lingkungan, Jakarta: PT. Gramedia, 1995

Sato, Masahisa, Teaching Methodology Option for Environment Education, JICA Training Materials. Revised Edition, 2000

Schutz, William, Joy: Expanding Human Awareness, New York: Grove Press, Inc., 1967

Schwab, Joseph, Biology Teachers' Handbook, New York: John Willey \& Sons, Inc., 1965

Semiawan, Conny \& Raka Joni, Pendekatan Pembelajaran, Acuan Konseptual Pengelolaan KBM di Sekolah, Jakarta: Konsorsium Pendidikan Ditjen Dikti Depdibud, 1993

Skinner, B. F., Science and Human Behavior, New York: Macmillan, Inc., 1953

Soekamto, Toeti dan Udin S. Winataputra, Teori Belajar dan Model-model Pembelajaran, Jakarta: P2T Universitas Terbuka, 1997

Soemarwoto, Otto, Ekologi Lingkungan Hidup dan Pembangunan, Jakarta : Djambatan, 1989

Soerjani, Mohamad, Pembangunan dan Lingkungan Meniti Gagasan dan Pelaksanaan Sustainable Development, Jakarta: Institut Pendidikan dan Pengembangan Lingkungan, 1997

Sudirman, N., dkk, Ilmu Pendidikan, Bandung: Remaja Rosda Karya, 1992
Sudjana, Nana, Teori-teori Belajar untuk Pengajaran, Jakarta: Universitas Indonesia, 1990

Sudjana, Metoda Statistika, Bandung: Tarsito, 2002

Sukmadinata, Nana S., Pendekatan Penelitian dan Pengembangan Pendidikan, Bandung: UPI, 2002

Sund \& Trowbridge, Teaching Science by Inquiry in the Secondary School, Columbus: Charles E. Merill Publishing Company, 1973

Suparman, Atwi, Desain Instruksional, Jakarta: PAU Ditjen Dikti Depdikbud, 1992

Suriasumantri, Jujun, Filsafat Ilmu Sebuah Pengantar Populer, Jakarta: Pustaka Sinar Harapan, 2000

Swan, J. A., Some Human Objectives for Environmental Education in Swan, J. A. \& Stapp, W. B. (ed). Environmental Education : Strategis toward a more livable future, New York: John Wiley \& Sons, 1974

Syah, Muhibin, Psikologi Pendidikan, Bandung: Rosdakarya, 1995

Taba, Hilda, Teaching Strategies and Cognitive Functioning in Elementary School Children, San Francisco: San Francisco State College, 1966

UNESCO, Trends in Environmental Education, Belgrade, 1977

Wartono,Pengembangan Model Pembelajaran Inkuiri Akrab Lingkungan untuk Mengembangkan Keterampilan Berpikir dan Meningkatkan Prestasi Belajar Siswa dalam Bidang Sains di SD (Studi Eksperimen untuk Menguji Efektivitas Model Pembelajaran Inkuiri Akrab Lingkungan pada Pokok Bahasan Energi dan Panas di SD Kota Madya Malang), Disertasi, Bandung: IKIP, 1996

Wiersma,James, Michael D. Morgan, Joseph M. Moran, Introduction to Environmental Science, New York, USA : W.H. Freeman and Company, 1986

Yusuf, Maftuchah, Pendidikan Kependudukan dan Etika Lingkungan, Jogjakarta: Lembaga Studi dan Inovasi Pendidikan, 2000

\begin{tabular}{|c|c|c|c|}
\hline Volume XI & Nomor 02 & Maret 2010 & ISSN 1411-1829 \\
\hline
\end{tabular}

